\title{
Review \\ Pharmacometabolomics Applied to Personalized Medicine in Urological Cancers
}

\author{
Filipa Amaro 1,2,*, Márcia Carvalho 1,2,3,4 $\left(\mathbb{D}\right.$, Maria de Lourdes Bastos ${ }^{1,2}$, Paula Guedes de Pinho 1,2 $^{\mathbb{D}}$ \\ and Joana Pinto $1,2, *$ (D)
}

check for updates

Citation: Amaro, F.; Carvalho, M.; Bastos, M.d.L.; Guedes de Pinho, P.; Pinto, J. Pharmacometabolomics

Applied to Personalized Medicine in Urological Cancers. Pharmaceuticals 2022, 15, 295. https://doi.org/ $10.3390 /$ ph15030295

Academic Editor: Giorgio Cozza

Received: 10 February 2022

Accepted: 25 February 2022

Published: 28 February 2022

Publisher's Note: MDPI stays neutral with regard to jurisdictional claims in published maps and institutional affiliations.

Copyright: (c) 2022 by the authors. Licensee MDPI, Basel, Switzerland. This article is an open access article distributed under the terms and conditions of the Creative Commons Attribution (CC BY) license (https:// creativecommons.org/licenses/by/ $4.0 /)$.
1 Associate Laboratory i4HB-Institute for Health and Bioeconomy, Department of Biological Sciences, Laboratory of Toxicology, Faculty of Pharmacy, University of Porto, 4050-313 Porto, Portugal; mcarv@ufp.edu.pt (M.C.); mlbastos@ff.up.pt (M.d.L.B.); pguedes@ff.up.pt (P.G.d.P.)

2 UCIBIO/REQUIMTE, Department of Biological Sciences, Laboratory of Toxicology, Faculty of Pharmacy, University of Porto, 4050-313 Porto, Portugal

3 FP-I3ID, FP-ENAS, CEBIMED, University Fernando Pessoa, 4200-150 Porto, Portugal

4 Faculty of Health Sciences, University Fernando Pessoa, 4200-150 Porto, Portugal

* $\quad$ Correspondence: famaro@ff.up.pt (F.A.); jipinto@ff.up.pt (J.P.); Tel.: +351-220428599 (F.A. \& J.P.)

\begin{abstract}
Prostate cancer $(\mathrm{PCa})$, bladder cancer $(\mathrm{BCa})$, and renal cell carcinoma $(\mathrm{RCC})$ are the most common urological cancers, and their incidence has been rising over time. Surgery is the standard treatment for these cancers, but this procedure is only effective when the disease is localized. For metastatic disease, $\mathrm{PCa}$ is typically treated with androgen deprivation therapy, while $\mathrm{BCa}$ is treated with chemotherapy, and RCC is managed primarily with targeted therapies. However, response rates to these therapeutic options remain unsatisfactory due to the development of resistance and treatment-related toxicity. Thus, the discovery of biomarkers with prognostic and predictive value is needed to stratify patients into different risk groups, minimizing overtreatment and the risk of drug resistance development. Pharmacometabolomics, a branch of metabolomics, is an attractive tool to predict drug response in an individual based on its own metabolic signature, which can be collected before, during, and after drug exposure. Hence, this review focuses on the application of pharmacometabolomic approaches to identify the metabolic responses to hormone therapy, targeted therapy, immunotherapy, and chemotherapy for the most prevalent urological cancers.
\end{abstract}

Keywords: prostate cancer; bladder cancer; renal cell carcinoma; pharmacometabolomics; biomarkers; treatment response

\section{Introduction}

The incidence and mortality of cancer tend to increase over the next years as a reflection of population aging and growth [1-3]. Incidence rates broadly vary between sexes and world regions due to differences in lifestyle habits (e.g., diet, nutrition, physical activity), exposure to risk factors, and disparities in quality of cancer prevention, diagnosis, and treatment [4]. The most recent data from GLOBOCAN [2] estimated 19.3 million new cancer cases and 10.0 million deaths worldwide in 2020. Considering the urinary system, prostate cancer $(\mathrm{PCa})$, bladder cancer $(\mathrm{BCa})$, and kidney cancer $(\mathrm{KCa})$ are the most common malignancies. PCa represented the most incident urological cancer in 2020, accounting for more than half of all diagnosed cases. Furthermore, PCa ranked 3rd in the list of most prevalent cancers according to GLOBOCAN [2]. BCa was the 2nd most prevalent urological cancer, ranking in the 11th position among the worldwide most common cancers, while KCa was the 3rd most prevalent urological cancer, ranking in the 15 th position among the most common cancers [2]. Renal cell carcinoma (RCC) represented more than $90 \%$ of all KCa diagnoses [5] and can be divided according to different histological subtypes into clear-cell RCC (ccRCC), which constitutes 75\% of all RCC cases [6], and the remaining $20 \%$ included the papillary and chromophobe RCC subtypes, among other rare types [6,7]. 
Testicular, penile, and urethral cancers are also classified as urological cancers; however, due to their low prevalence worldwide ( $1 \%)$, they were not included in this review.

Significant progress has been made in the understanding of hallmarks underlying the development of urological cancers and the identification of novel molecular markers to improve treatment effectiveness [8]. Currently, a vast spectrum of therapeutic approaches is available to treat urological cancers. Surgery, chemotherapy, and radiation therapy are the most used cancer treatments [9]. Other modalities, namely hormonal, targeted, and immune therapies, have emerged in recent years to improve or overcome the low specificity of traditional therapeutic approaches, demonstrating significant clinical benefits in patient outcomes [10]. However, the development of resistance after long-term exposure continues to jeopardize the efficacy of chemotherapy, hormone therapy, and targeted therapy [11-13], and only a small percentage of patients respond to immunotherapy [14,15], depending on the identification of predictive biomarkers of therapeutic response.

In this regard, personalized medicine seeks to identify the most appropriate treatment option for a patient, considering both its individual genetic and non-genetic characteristics, to guide more informed clinical decisions, reducing adverse effects and associated costs [8,16-18]. In personalized medicine, cancer patients must be divided into distinct subgroups so that the optimal/most precise treatment can be prescribed at the right time [19]. As a result, the conventional "one treatment fits all" paradigm, in which treatment is used in a universal population approach regardless of individual genes, environments, and lifestyles, is changing [20]. The use of reliable cancer classifiers can help clinicians to correctly stratify patients to predict their therapeutic responses. Hence, pharmacogenomic studies have been conducted to investigate the influence of inter and intra-patient genetic variabilities on drug response [21]. However, pharmacogenomics does not consider other important factors that may affect therapeutic responses (e.g., gender, nutrition, age, health status, among others) [22]. These factors, as well as the disease state, can alter the metabolic profile (metabolome) of an individual, making metabolome analysis during a treatment regimen a promising strategy for identifying biomarkers of therapeutic response. Thus, pharmacometabolomics emerges to perform metabolic profiling of an individual prior, during, and after a treatment to identify potential metabolic biomarkers that can predict patient treatment response, which is of utmost interest in precision medicine [22,23]. This review focuses on the pharmacometabolomic studies that have been conducted over the last twelve years (2010 to 2021) to investigate biomarkers of therapeutic response in the most incident urological cancers, namely $\mathrm{PCa}, \mathrm{BCa}$, and RCC.

\section{Current Status and Limitations of Therapies for Urological Cancers}

The standard management of urological cancers initiates with surgery. However, alternative options must be used to control cancer progression at the metastatic stages. In this section, the most used strategies in the treatment of each urologic cancer are reviewed, starting with the most prevalent-PCa, followed by BCa and RCC.

\subsection{Prostate Cancer}

$\mathrm{PCa}$ is a complex disease with a large spectrum of aggressiveness, from localized $\mathrm{PCa}$, which corresponds to $77 \%$ of the diagnosed PCa cases, to advanced/metastatic disease [24]. For low risk of progression (localized PCa) cases, surgery is recommended (prostatectomy) besides surveillance to prevent the substantial associated risk to develop recurrences [25-27]. Radiation therapy can also be prescribed for low- and intermediate-risk cases and can be divided into two major types: external beam radiation and brachytherapy $[25,28]$. External beam radiation is addressed to the prostate gland using high-energy rays from a machine outside the body. In turn, brachytherapy uses small radioactive particles, also called pellets or "seeds", that are put directly into the prostate [28]. However, PCa can spread limiting its management by surgery or radiation and, therefore, patients can experiment relapses. In these cases, androgen deprivation therapy (ADT), also known as hormone therapy, is considered [29]. Male hormones, namely testosterone, are essential 
for prostate cancer development, maintenance, and progression [30]. ADT decreases the concentration of androgens in body circulation using gonadotropin-releasing hormones (GnRH) agonists (e.g., leuprolide, goserelin, triptorelin, histrelin) and antagonists (e.g., degarelix) as well as androgen inhibitors (e.g., bicalutamide, nilutamide, flutamide, enzalutamide) $[29,30]$. The most used hormone therapy drugs are listed in Table 1. Despite the benefits, several adverse effects have been associated with ADT including sexual side effects (e.g., loss of libido, erectile dysfunction, among others), osteoporosis, anemia, fatigue, depression, and cardiovascular complications [31]. Moreover, after an initial response to ADT, some patients develop castration-resistant $\mathrm{PCa}$ (CRPCa), a progression of the disease [32]. Novel anti-androgen drugs such as bicalutamide, nilutamide, or enzalutamide have been developed to treat this condition but the prognosis of CRPCa remains poor [25,32]. In these cases, ADT is commonly recommended for symptom control or prescribed in combination with chemotherapy (e.g., docetaxel, cabazitaxel, mitoxantrone) to slow the progression of advanced PCa $[28,30]$. Additionally, pharmaceutical compounds like olaparib and rucaparib were recently approved by the FDA for targeted therapy in patients with metastatic or hormone-resistant PCa who have mutations in breast cancer genes (BRACs), which are well-established tumor suppressor genes that maintain genomic stability [33,34].

The use of diagnostic biomarkers, such as the serum prostate-specific antigen (PSA), which is commonly used for PCa screening, prostatic acid phosphate (PAP), and prostatespecific membrane antigen (PSMA), as target antigens in immunotherapy has been investigated [32,35]. Moreover, the scientific community has been interested in combining immunotherapy and targeted therapy to increase the sensitivity of cancer cells to antitumor effects of antineoplastic drugs [36].

Apart from efforts to improve PCa therapeutics, reliable biomarkers for patient stratification and outcome prediction are urgently needed [32].

\subsection{Bladder Cancer}

Transitional cell carcinoma, which represents $90 \%$ of all BCa cases, presents distinct histological variants associated with different clinical features and outcomes [37]. Management of $\mathrm{BCa}$ is based on the pathological findings of the biopsy (histology, grade, and invasion), accomplished during the cystoscopy [38]. Local disease, also known as nonmuscle-invasive $\mathrm{BCa}$ (NMIBC), is treated with transurethral resection of the bladder tumor (TURBT). However, approximately $20 \%$ of all NMIBC cases progress to muscle-invasive $\mathrm{BCa}$ (MIBC) which treatment is accomplished with radical cystectomy with pelvic node dissection [39]. Additionally, surgery is frequently combined with cisplatin-based neoadjuvant chemotherapy, which has been considered the first-line treatment for metastatic $\mathrm{BCa}[38,40]$. Cisplatin-based treatment encompasses significant benefits for the patient, but it also causes several side effects and toxicity. Furthermore, it has a low response rate $(40-50 \%)$ due to the development of resistance mechanisms during long-term exposures [41,42].

To address the drawbacks of chemotherapy, recent research has demonstrated the antitumoral activity of immune checkpoint inhibitors such as pembrolizumab and atezolizumab in BCa management [42]. These pharmaceutical compounds are currently recommended as first-line treatment for advanced $\mathrm{BCa}$ and non-responding or non-eligible chemotherapy BCa patients $[39,43]$.

Mutations on FGFR3 or FGFR2 genes are usually associated with the presence of cancer. Indeed, FGFR3 has been used as a prognostic and predictive marker for less aggressive forms of $\mathrm{BCa}$, as well as a therapeutic target of erdafitinib, which is typically recommended for cases of recurrent $\mathrm{BCa}[41,44]$. These findings enhance the clinical benefits of identifying driving changes in the development of patient-specific therapies. In this vein, the possibility of predicting sensitivity to phosphatidylinositol 3-kinase/mammalian target of rapamycin (PIK3/mTOR) inhibitors has already been reported through the identification of mutations in the PIK3CA genes, that occur in approximately $26 \%$ of BCa patients [45].

Despite the advances in BCa management, response to treatment is still non-durable and cisplatin therapy is associated with significant treatment-related toxicity. Strategies 
for optimization of drug doses and drug combinations must be established in order to avoid drug overexposure. Moreover, the identification of early signs of resistance can help researchers gain a better understanding of the mechanisms that underpin resistance development.

\subsection{Renal Cell Carcinoma}

RCC is recognized as a metabolic disease characterized by deregulations on several processes including angiogenesis (e.g., von Hippel-Lindau/hypoxia-inducible factor gene mutations) [46], energy metabolism (Warburg effect), and nutrient-sensing pathways [47,48]. This heterogeneity impairs the selection of RCC therapeutics, hence, the definition of prognostic and predictive elements of therapeutic response is of utmost importance. Approximately $65 \%$ of all RCC diagnosed cases are confined to the kidney and can be successfully managed with surgery (total or partial nephrectomy), with a 5-year relative survival rate of $93 \%[49,50]$. Despite the recognition of surgery as the standard treatment for localized RCC, in some particular cases, radiotherapy can be considered using a radiation source outside the body [7,51]. For metastatic RCC patients, the survival rate decreases significantly to 70\% when cancer spreads to near structures of the kidney (e.g., lymph nodes) and $12 \%$ when cancer spreads to distant parts of the body [49]. In these cases, and when patients experience relapses after local therapy, systemic treatment is required. The systemic treatment begins with first-line therapies that include inhibitors of tyrosine kinases (e.g., vascular endothelial growth factor (VEGF) receptors), as sunitinib, pazopanib, tivozanib and cabozantinib, and mTOR, as temsirolimus and everolimus [7,52]. More recently, the combination of these targeted drugs with immunotherapeutic agents (ipilimumab/nivolumab or pembrolizumab/axitinib) has been approved $[53,54]$. Resistance acquisition is an important phenomenon in RCC in both targeted and immune therapies that contributes to limited long-term responses and, consequently, a poor prognosis [55]. The discovery of biomarkers that predict drug efficacy can help to avoid these problems, reducing costs and improving patient survival [56]. Ongoing and future clinical trials must delve deeper into the subset of patients who do not respond to current therapies. Chemotherapy is not recognized as a usual treatment for RCC due to low associated response rates [57].

\section{Pharmacometabolomics}

\subsection{The Concept}

Molecular profiling of tumors using genomics, proteomics, and metabolomics approaches can assist clinicians in patient stratification [8]. Pharmacogenomics, broadly defined as the study of individual genetic profiles to predict the therapeutic response of patients, has been used as a route to perform precision medicine but it is not sensitive to environmental factors (e.g., diet, age, nutrition, gender, lifestyle, gut microbiome among others) that also influence the response of a patient or a group of patients to the drug therapy [58]. Thus, pharmacometabolomics was defined in 2006 as "an enhanced understanding of mechanisms for drug or xenobiotic effect and increased ability to predict individual variation in drug response phenotypes, based on using both baseline metabolic profiles prior to treatment and also effects of drug treatment over time" [59]. Since metabolic changes precede phenotypic changes, pharmacometabolomics is a powerful tool to predict therapeutic responses based on the discovery of similar metabolic signatures of a group of patients pre- and post-treatment (metabotypes) $[22,59,60]$. These metabolic signatures refer to several low-molecular-weight endogenous and exogenous metabolites including amino acids, fatty acids, organic acids, carbohydrates, among others, and their levels can be used to build models of patient response to a drug (including toxicity and side effects) [61]. In the realm of precision medicine, the analysis of perturbations in the levels of these chemical compounds is critical to select biomarkers capable of predicting responses and monitoring the health status of a patient during treatment [62]. 


\subsection{Workflow}

The design of a pharmacometabolomic study constitutes an important point before its beginning to ensure optimal sample handling, metabolite extraction, detection, and interpretation to guarantee the reproducibility of the results [23]. Since the primary goal of pharmacometabolomics in the biomarker discovery field relies on the assumption that the metabolic fingerprint is altered by treatment response, resistance, and/or toxicity, the workflow initiates with the collection of biological samples before (baseline) and after treatment (Figure 1). The second step in the pharmacometabolomics pipeline is data acquisition which includes metabolite detection by high-throughput analytical techniques. Data generated in the second step must be processed into a manageable format using bioinformatic tools before being subjected to multivariate and univariate statistical methods. The final step entails data interpretation to identify potential biomarkers of therapeutic response (e.g., biomarkers of efficacy, toxicity, pharmacokinetics, and pharmacodynamics) to build mathematical models capable of predicting therapeutic responses.

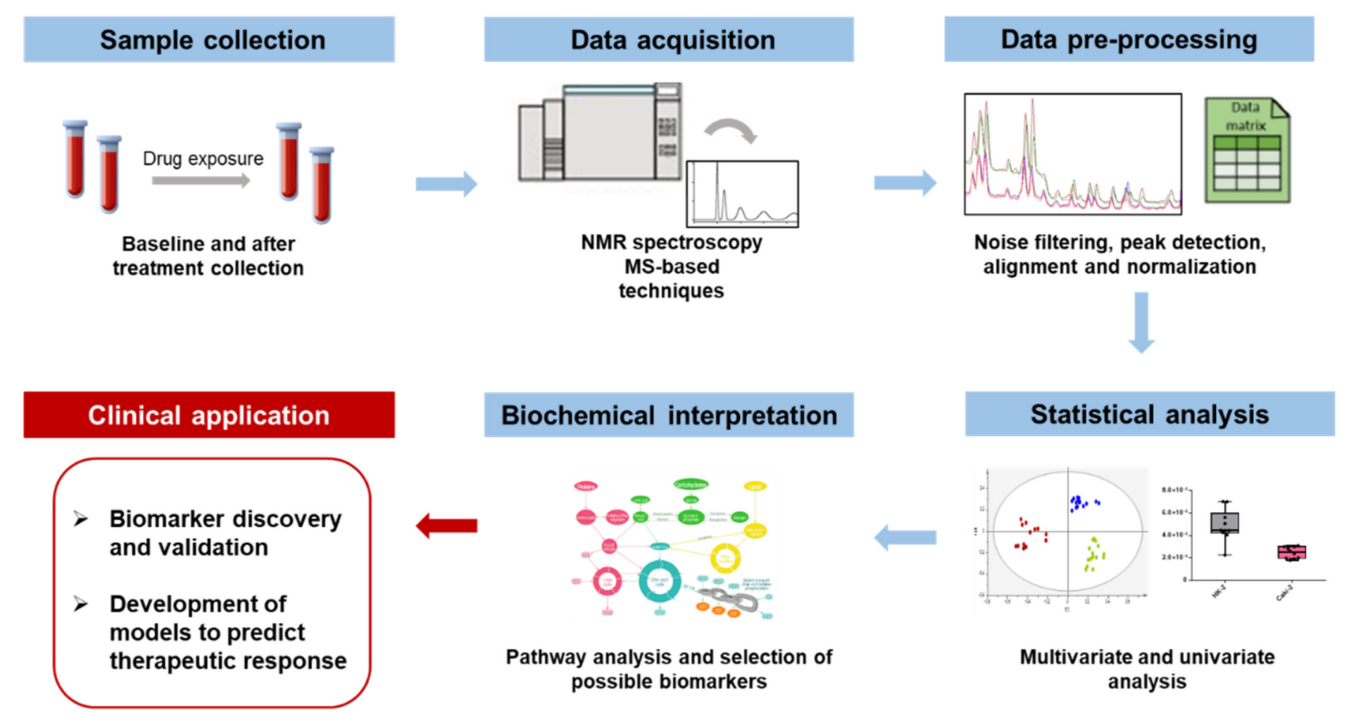

Figure 1. Overview of a representative pharmacometabolomics workflow and its main goals.

The biological matrices most used in pharmacometabolomic studies include blood plasma/serum, tissues, and cells and they are collected prior to treatment at the baseline, followed by collection during and after treatment. Serum and plasma are complex matrices that are broadly used to monitor drug responses and can be collected at different time points (e.g., routine clinical follow-ups) [63]. Tissue samples require an invasive collection, and the representativeness of the tissue sample is compromised by the heterogeneity of the tumor; notwithstanding, they allow for the evaluation of the metabolites at their origin, i.e., in the specific organ [64]. For urological cancer studies, tissue can be collected during surgeries (e.g., prostatectomy, nephrectomy, and cystectomy), which are the primary treatment modality for most of them, in order to address implications of a previous drug exposure (e.g., adjuvant chemotherapy). However, recruiting a significant number of participants to collect human samples remains a challenge in pharmacometabolomic studies, making it necessary to investigate other biological models. Indeed, some studies referred to the use of biological samples from less complex models, such as in vitro and animal models including the cell line-derived xenograft (CDX), for accessing in vivo therapeutic responses. In vitro models provide an easier comprehension of drugs action and aid in their rapid incorporation into novel therapeutic settings [65,66]. Patient-derived xenografts (PDX) are models in which the tissue or cells from a patient's tumor are implanted into an animal model (typically mice), allowing researchers to track the dynamics and progression of 
cancer (e.g., development of treatment resistance) while preserving tumor heterogeneity, genomic, and histological characteristics [67].

Regarding the analytical techniques used in pharmacometabolomics studies, nuclear magnetic resonance spectroscope (NMR) and mass spectrometry-based (MS) have been widely used in metabolomics studies [68]. Each one presents specific advantages and limitations in terms of sensitivity, reproducibility, and equipment costs [69]. No single analytical technique can provide complete coverage of the human metabolome which is composed of numerous metabolites from different classes with varying concentrations and physicochemical properties [68]. As a result, the combination of both NMR and MS-based platforms allows for a more accurate characterization of the physiologic, pathologic, and treatmentspecific metabolites [70,71]. Despite this, the majority of pharmacometabolomic studies are limited to a single technique.

Translating the complex and non-linear data generated by NMR and MS methods to a model that can predict patient response to a drug is challenging. Thus, data pre-processing is a paramount step to prepare the raw data into a format that can be interpreted by multivariate analysis [72]. In general, the basic tools for data pre-processing include noise filtering and baseline correction, peak detection and deconvolution, alignment, and normalization [73]. Then, appropriate unsupervised and supervised multivariate analysis can ensure the extraction of useful information from experimental data [74,75]. Principal component analysis (PCA) is an unsupervised method to easily detect trends and outliers among samples, without considering sample identity. Hierarchical cluster analysis is also commonly used to build a tree diagram based on the similarity or differences between sample groups (clusters). Supervised methods, such as partial least squares-discriminant analysis (PLS-DA) and the orthogonal PLS-DA (OPLS-DA), consider a previous classification of samples to build the projection, maximizing the differences between samples [72]. Due to the risk of overfitting, model robustness must be evaluated through cross-validation or permutation tests and, if possible, using an independent set of data to build the models [72]. Univariate analysis (e.g., ANOVA, $t$-tests) is commonly used to evaluate the statistical significance of the biomarkers. To avoid the chance of false-positive results, $p$-values can be corrected for multiple comparisons using Bonferroni correction or the false discovery rate [72].

Discriminant metabolites identified can be further investigated to understand derangements in pathways that underlie drug response [22]. Several integration databases for enrichment analysis are available (e.g., MetaboAnalyst [76], Kyoto Encyclopedia of Genes and Genomes (KEGG) [77]) that can simplify the biochemical interpretation and relevance of the potential biomarkers $[72,75]$.

\section{Pharmacometabolomic Studies in Urological Cancers}

The goal of pharmacometabolomic studies performed in the urological cancers field is to identify discriminative metabolites between samples collected before and after a drug treatment to advance with candidate biomarkers and mechanistic pathways of treatment response. In this section, a review of the literature was performed to access studies that apply pharmacometabolomic approaches to identify the metabolic responses to hormone therapy, immunotherapy, targeted therapy, and chemotherapy in PCa, BCa, and RCC. The identification of papers was conducted through a search on the PubMed database considering the following keywords or expressions [(metabolomics OR "metabolic profiling") AND (chemotherapy OR "targeted therapy" OR immunotherapy OR "hormone therapy" OR "endocrine therapy" OR "androgen deprivation therapy" OR resistance) AND ("prostate cancer" OR "bladder cancer" OR "renal cancer" OR "kidney cancer" OR "renal cell carcinoma")]. The search was performed in December 2021, considering all literature published in English from 2010 to 2021. In total, the search retrieved 163 papers (Figure 2). After an initial screening, 59 review papers and comments were excluded. The remaining 104 records of original results were analyzed, and 68 articles were excluded due to the lack of relevance for the topic, 10 articles reporting results with alternative pharmaceutical com- 
pounds, and 5 articles using other omics approaches. Finally, 18 articles were considered for the present review.

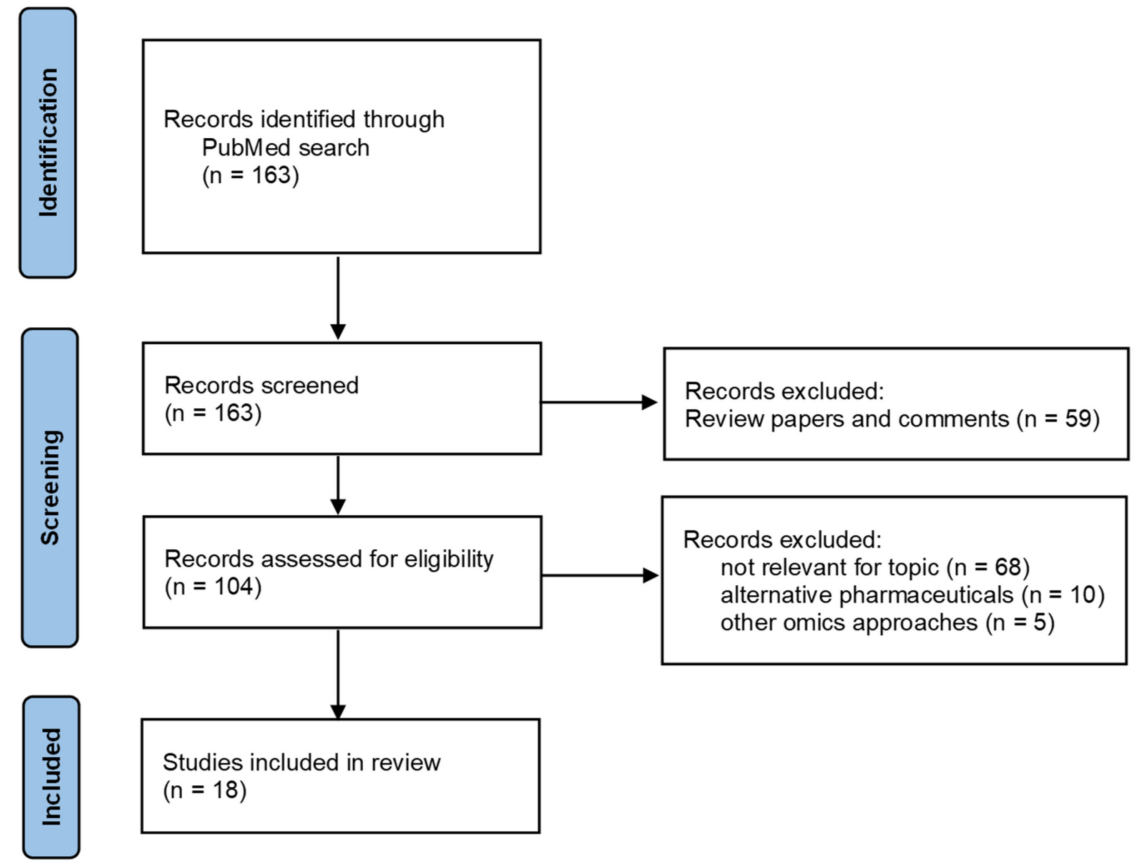

Figure 2. Flow diagram of literature search (time frame: 2010-2021; database: PubMed).

\subsection{Pharmacometabolomic Studies in Prostate Cancer}

PCa is the most studied urological cancer using pharmacometabolomic approaches with ten studies reported from 2010 to 2021. Table 1 summarizes the study design and main findings from those reports, including the pattern of metabolites with the potential to be candidate biomarkers of therapeutic response and the related metabolic pathways. Because castration resistance is a common condition in $\mathrm{PCa}$, specific biomarkers associated with resistance development are also discussed in the research studies. Early biomarkers of resistance must be identified to optimize treatment regimens and improve long-term outcomes.

Three studies aiming to monitor the treatment response of PCa cells were performed using in vitro models [78-80]. Lodi et al. [78] used ${ }^{1} \mathrm{H}$ NMR spectroscopy to assess the effects of treatment with the phosphatidylinositol 3-kinase (PI3K) inhibitor LY294002 and the heat shock protein 90 (HSP90) inhibitor 17AAG on the metabolome of two PCa cell lines. These compounds belong to the group of targeted therapy approaches, whose clinical interest has increased in the last few years. The pharmacometabolomic analysis was complemented with Western blotting to confirm the inhibition of the target proteins. The results showed that LY294002 treatment increased intracellular levels of glutamine and several branched-chain amino acids (BCAAs), such as valine, leucine, and isoleucine, while decreasing levels of lactate, alanine, fumarate, phosphocholine, and glutathione were observed. Regarding 17AAG, PCa-exposed cells demonstrated a similar increasing tendency in the levels of BCAAs, as well as increases in phosphocholine, myo-inositol, taurine, and citrate, and decreases in lactate, alanine, fumarate, and glutamine levels. Both inhibitors induced intracellular metabolic alterations (lactate, alanine, and fumarate) that may be associated with the activation of glucose uptake and glycolysis by PI3K-protein kinase B/Akt (PI3K/Akt) signaling. The alterations in intracellular glutamine levels unveiled some specificity for the treatment type, with an increase following PI3K inhibition (LY294002) and a decrease following HSP90 inhibition (17AA treatment), indicating a potential role of glutaminolysis in cancer cell growth. Citrate is typically found in high concentrations in healthy prostate tissue due to the specific metabolism of prostate cells that 
accumulates this metabolite rather than oxidizing it for energy production [71]. For this reason, the increase in intracellular concentration of citrate after 17AAG treatment may indicate a specific shift to a more physiological behavior of PCa cells. Furthermore, the process of obtaining energy is switched to glycolysis rather than oxidative phosphorylation in $\mathrm{PCa}$, resulting in an increase in the levels of glucose and lactate compared to normal cells $[71,81]$. Given this, the decreased levels of lactate in PCa cells after treatment, found by Lodi et al. [78], suggested its effectiveness. Because tumors rely on BCAA intake for energy, their intracellular accumulation appears to indicate a slowdown of protein synthesis and, consequently, a decrease in cell proliferation and cancer progression [78,82]. The alterations found in common in both cell lines suggested that several metabolites are simultaneously modulated following treatment.

The in vitro study performed by Qu et al. [79] aimed to study the antitumor effects of proxalutamide and two others currently used androgen receptor (AR) antagonists (bicalutamide and enzalutamide) on AR-positive (LNCaP and 22RV1) and AR-negative PCa cell lines through liquid chromatography quadrupole time-of-flight mass spectrometry (LC-Q/TOF-MS). The results unveiled that proxalutamide significantly decreased the intracellular levels of glutamine, glutamate, cysteine, glycine, reduced glutathione (GSH), oxidized glutathione (GSSG), aspartate, uridine, cytidine, and thymidine in AR-positive cells, while no effect was observed on the intracellular levels of AR-negative cell lines. These changes suggested that proxalutamide inhibited glutamine metabolism, redox homeostasis (glutathione metabolism), and pyrimidine synthesis in AR-positive cells. Moreover, a reduction in the expression of cell surface transporters necessary for glutamine intake was noted through Western blot assays.

In the third study, the metabolic dysregulations in castration-resistant PCa compared to androgen-dependent PCa were investigated in in vitro and animal models by targeted NMR spectroscopy analysis of metabolites involved in the metabolism of [U- ${ }^{13} \mathrm{C}$ ]-glucose and [U- $\left.{ }^{13} \mathrm{C}\right]$-glutamine [80]. The in vitro model comprised the intracellular metabolites of human PCa cell lines representative of androgen-dependent PCa (LNCaP) and castrationresistant $\mathrm{PCa}(\mathrm{PC} 3)$, which were cultured with ${ }^{13} \mathrm{C}$-glucose and ${ }^{13} \mathrm{C}$-glutamine media. In the animal model, aqueous extracts of solid tumor masses from the transgenic adenocarcinoma of mouse prostate (TRAMP) mice were analyzed. The results unveiled higher levels of amino acids, membrane precursors, and organic acids from energy metabolism in the resistant condition, indicating a higher energetic and biosynthetic demand to support cell survival and growth. Interestingly, this study reported an increase in the levels of glutamate (an intermediate in glutathione metabolism) as well as glutathione, an antioxidant agent that can protect resistant cells from the cytotoxic effects of drugs, thereby supporting the development of drug resistance [80,83].

Human samples have been the preferred model for pharmacometabolomic studies of PCa, but the number of available samples collected before and after treatments has been limited. Table 1 summarizes seven pharmacometabolomic studies performed in serum, plasma, and tissue from PCa patients under hormone therapy (androgen deprivation therapy) [84-88] and chemotherapy regimens [89,90]. The first study was performed by Saylor et al. [84] to investigate changes in plasmatic metabolite levels in patients receiving a gonadotropin-releasing hormone (GnRH) agonist using both GC-MS and LC-MS/MS. The main alterations observed in plasma extracts after 3 months of treatment exposure included an increase in the levels of cholate (an intermediate of bile acid metabolism) and a decrease in the levels of steroids and metabolites from lipid $\beta$-oxidation (several carnitines and ketone bodies), effects which were associated with the use of androgen-deprivation therapy in PCa patients $[84,91]$. 
Table 1. Pharmacometabolomic studies performed in PCa.

\begin{tabular}{|c|c|c|c|c|c|}
\hline $\begin{array}{c}\text { Cancer Therapy } \\
\text { under Study }\end{array}$ & Samples & $\begin{array}{l}\text { Instrumental and } \\
\text { Statistical Analysis }\end{array}$ & Treatment Response & $\begin{array}{c}\text { Metabolic } \\
\text { Interpretation }\end{array}$ & Ref. \\
\hline $\begin{array}{c}\text { Targeted therapy: } \\
\text { PI3K inhibitor LY294002 } \\
(10-25 \mu \mathrm{M}) \text { and HSP90 } \\
\text { inhibitor 17AAG }(0.25-1 \mu \mathrm{M}) \\
48 \mathrm{~h} \text { of treatment exposure }\end{array}$ & $\begin{array}{l}\text { Intracellular (polar) metabolome } \\
\text { of PCa cell lines: } \\
\text { PC3 untreated (DMSO solvent } \\
\text { control), } n=8 \\
\text { treated with LY294002, } n=8 \\
\text { treated with 17AAG, } n=8 \\
\text { LNCaP untreated (DMSO solvent } \\
\text { control), } n=8 \\
\text { treated with LY294002, } n=8 \\
\text { treated with 17AAG, } n=8\end{array}$ & $\begin{array}{c}{ }^{1} \mathrm{H} \text { NMR } \\
\text { PCA } \\
\text { Mann-Whitney U test }\end{array}$ & $\begin{array}{l}\text { nimal models } \\
\text { LY294002 treatment effects in both cell lines (PC3 } \\
\text { and LNCaP): } \\
\text { } \uparrow \text { valine; leucine; isoleucine; glutamine } \\
\downarrow \text { alanine; lactate; fumarate;glutathione; } \\
\text { phosphocholine } \\
\text { 17AAG treatment effects in both cell lines (PC3 and } \\
\text { LNCaP): } \\
\uparrow \text { valine; leucine; isoleucine; phosphocholine; } \\
\quad \text { myo-inositol; taurine; citrate } \\
\downarrow \text { lactate; alanine; fumarate; glutamine }\end{array}$ & $\begin{array}{l}\text { LY294002 and 17AAG } \\
\text { exposure activated glycolysis } \\
\text { by PI3K/Akt signaling and } \\
\text { influenced the glutaminolysis }\end{array}$ & [78] \\
\hline $\begin{array}{c}\text { Hormone therapy: } \\
\text { androgen receptor (AR) } \\
\text { antagonists proxalutamide, } \\
\text { bicalutamide, } \\
\text { and enzalutamide }(1-10 \mu \mathrm{M}) \\
48 \mathrm{~h} \text { of treatment exposure }\end{array}$ & $\begin{array}{l}\text { Intracellular (polar) metabolome } \\
\text { of PCa cell lines: } \\
\text { AR-positive cells (22RV1 and } \\
\text { LNCaP): } \\
\text { untreated, } n=6 \\
\text { treated with each AR antagonist, } \\
n=6 \text { per drug } \\
\text { AR-negative cells (PC3, DU145): } \\
\text { untreated, } n=6 \\
\text { treated with AR antagonist, } n=6 \\
\text { per drug }\end{array}$ & $\begin{array}{c}\text { LC-Q/TOF-MS } \\
\text { PCA, PLS-DA, OPLS-DA } \\
\text { Two-tailed student's } t \text {-test } \\
\text { One-way analysis of } \\
\text { variance }\end{array}$ & $\begin{array}{l}\text { Proxalutamide treatment effects in both AR-positive } \\
\text { cell lines: } \\
\downarrow \text { glutamine; glutamate; GSH; GSSG; GSH/GSSG; } \\
\text { glycine; aspartate; uridine, cytidine; thymidine } \\
\text { Bicalutamide treatment effects in AR-positive cell } \\
\text { lines: } \\
\downarrow \text { thymidine } \\
\text { Enzalutamide treatment effects in AR-positive cell } \\
\text { lines: } \\
\downarrow \text { GSH } \\
\uparrow \text { aspartate } \\
\text { No significant changes were found for } \\
\text { proxalutamide, bicalutamide, and enzalutamide in } \\
\text { AR-negative cell lines }\end{array}$ & $\begin{array}{l}\text { Proxalutamide exposure } \\
\text { inhibited glutamine } \\
\text { metabolism, glutathione } \\
\text { metabolism and pyrimidine } \\
\text { metabolism }\end{array}$ & [79] \\
\hline Hormone therapy & $\begin{array}{l}\text { Intracellular (polar) metabolome } \\
\text { of cell lines: } \\
\text { AR-positive cells: } \\
\text { LNCaP, } n=4 \\
\text { Castration resistant cells: } \\
\text { PC }, n=4 \\
\text { Tissue extract (polar phase): } \\
\text { TRAMP, } n=3 \\
\text { castrate resistant TRAMP, } n=3\end{array}$ & $\begin{array}{c}{ }^{1} \mathrm{H} \text { NMR } \\
\text { Student's } t \text {-test }\end{array}$ & $\begin{array}{c}\text { Castration resistant condition effects in cell lines: } \\
\uparrow \text { aspartate; glutamate; lactate; myo-inositol; } \\
\text { phosphocholine; glycerophosphocholine; total } \\
\text { choline; alanine; glutathione } \\
\downarrow \text { citrate; glucose; creatine; creatine phosphate } \\
\text { Castration resistant condition effects in TRAMP: } \\
\uparrow \text { lactate; aspartate; glutamate; glutathione } \\
\downarrow \\
\downarrow \text { citrate; creatine }\end{array}$ & $\begin{array}{l}\text { Castration resistant condition } \\
\text { was associated with an } \\
\text { upregulation of glycolysis; } \\
\text { TCA cycle; glutaminolysis } \\
\text { and glutathione synthesis }\end{array}$ & [80] \\
\hline
\end{tabular}


Table 1. Cont.

\begin{tabular}{|c|c|c|c|c|c|}
\hline $\begin{array}{c}\text { Cancer Therapy } \\
\text { under Study }\end{array}$ & Samples & $\begin{array}{c}\text { Instrumental and } \\
\text { Statistical Analysis }\end{array}$ & Treatment Response & $\begin{array}{c}\text { Metabolic } \\
\text { Interpretation }\end{array}$ & Ref. \\
\hline $\begin{array}{c}\text { Hormone therapy: leuprolide } \\
\text { (22.5 mg IM 3-month depot) } \\
\text { and bicalutamide ( } 50 \mathrm{mg} \text { per } \\
\text { day) } \\
4 \text { weeks of treatment } \\
\text { exposure }\end{array}$ & $\begin{array}{l}\text { Lipophilic and hydrophilic } \\
\text { plasma extracts: } \\
\text { PCa untreated group, } n=36 \\
\text { PCa treated group, } n=36\end{array}$ & $\begin{array}{c}\text { LC-MS/MS } \\
\text { GC-MS } \\
\text { Student's } t \text {-test }\end{array}$ & $\begin{array}{l}\text { Tan models } \\
\text { Hormone therapy effects in PCa treated group: } \\
\uparrow \text { cholate } \\
\downarrow \text { dehydroisoandrosterone sulfate; epiandrosterone } \\
\text { sulfate; androsterone sulfate; cortisol; } \\
\text { 4-androsten-3 } \beta, 17 \beta \text {-diol disulfates } 1 \text { \& } 2 ; \\
5 \alpha \text {-androstan-3 } \beta, 17 \beta \text {-diol disulfate; pregnendiol } \\
\text { disulfate; pregn steroid monosulfate; andro steroid } \\
\text { monosulfates } 1 \text {; deoxycarnitine; acetylcarnitine; } \\
\text { hexanoylcarnitine; octanoylcarnitine; } \\
\text { decanoylcarnitine; laurylcarnitine; } \\
\text { palmitoylcarnitine; stearoylcarnitine; } \\
\text { oleoylcarnitine; 3-hydroxybutyrate; acetoacetate; } \\
\text { dodecanedioate; octadecanedioate; } \\
\text { 2-hydroxybutyrate; } \alpha \text {-hydroxyisovalerate; 2- } \\
\text { methylbutyroylcarnitine }\end{array}$ & $\begin{array}{l}\text { Hormone therapy exposure } \\
\text { inhibited steroids synthesis, } \\
\text { fatty acid oxidation, bile acid } \\
\text { synthesis and BCAAs } \\
\text { synthesis }\end{array}$ & [84] \\
\hline $\begin{array}{c}\text { Hormone therapy: } \\
\text { bicalutamide and goserelin } \\
\text { up to } 2 \text { years of treatment } \\
\text { exposure }\end{array}$ & $\begin{array}{l}\text { Lipophilic serum extract: } \\
\text { PCa } \\
\text { untreated group, } n=18 \\
\text { treated group, } n=36 \\
\text { (poor response } n=18 \text { and } \\
\text { good response } n=18 \text { ) } \\
\text { Healthy group, } n=18\end{array}$ & $\begin{array}{c}\text { LC-MS } \\
\text { PLS-DA } \\
\text { OPLS } \\
\text { Duncan pairwise post hoc } \\
\text { tests }\end{array}$ & $\begin{array}{c}\text { Hormone therapy effects in PCa poor response } \\
\text { group: } \\
\uparrow \text { deoxycholic acid; glycochenodeoxycholate; } \\
\text { L-tryptophan; arachidonic acid; deoxycytidine } \\
\text { triphosphate; pyridinoline } \\
\downarrow \text { docosapentaenoic acid } \\
\text { Hormone therapy effects in PCa good response } \\
\text { group: } \\
\uparrow \text { L-tryptophan; arachidonic acid; deoxycholic acid; } \\
\text { glycochenodeoxycholate } \\
\downarrow \text { docosapentaenoic acid; pyridinoline; } \\
\text { deoxycytidine triphosphate }\end{array}$ & $\begin{array}{l}\text { Hormone therapy exposure } \\
\text { altered cholesterol metabolic } \\
\text { pathway }\end{array}$ & [85] \\
\hline $\begin{array}{l}\text { Hormone therapy: degarelix } \\
(240 \mathrm{mg}) \\
7 \text { days of treatment exposure }\end{array}$ & $\begin{array}{c}\text { Tissue extract (polar phase): } \\
\text { PCa } \\
\text { untreated group, } n=6 \\
\text { treated group, } n=7 \\
\text { Control group, } n=10\end{array}$ & $\begin{array}{c}{ }^{1} \mathrm{H}-\mathrm{NMR} \\
\text { PCAOPLS-DA }\end{array}$ & $\begin{array}{c}\text { Degarelix effects in PCa treated group: } \\
\downarrow \text { lactate; total choline }\end{array}$ & $\begin{array}{l}\text { Hormone therapy exposure } \\
\text { reduced glycolysis and } \\
\text { membrane phospholipid } \\
\text { metabolism }\end{array}$ & [86] \\
\hline
\end{tabular}


Table 1. Cont.

\begin{tabular}{|c|c|c|c|c|c|}
\hline $\begin{array}{c}\text { Cancer Therapy } \\
\text { under Study }\end{array}$ & Samples & $\begin{array}{l}\text { Instrumental and } \\
\text { Statistical Analysis }\end{array}$ & Treatment Response & $\begin{array}{c}\text { Metabolic } \\
\text { Interpretation }\end{array}$ & Ref. \\
\hline $\begin{array}{l}\text { Hormone therapy: LHRH } \\
\text { agonist, LHRH-antagonist, } \\
\text { or orchiectomy } \\
3 \text { and } 6 \text { months of treatment } \\
\text { exposure }\end{array}$ & $\begin{array}{c}\text { Lipophilic and hydrophilic } \\
\text { serum extracts: } \\
\text { PCa } \\
\text { untreated group, } n=20 \\
\text { treated group ( } 3 \text { months), } \\
n=20 \\
\text { treated group (6 months), } \\
n=20\end{array}$ & $\begin{array}{c}\text { GC-TOF-MS } \\
\text { LC-HILIC-MS/MS } \\
\text { Volcano plot } \\
\text { ANOVA } \\
\text { Pearson correlation }\end{array}$ & 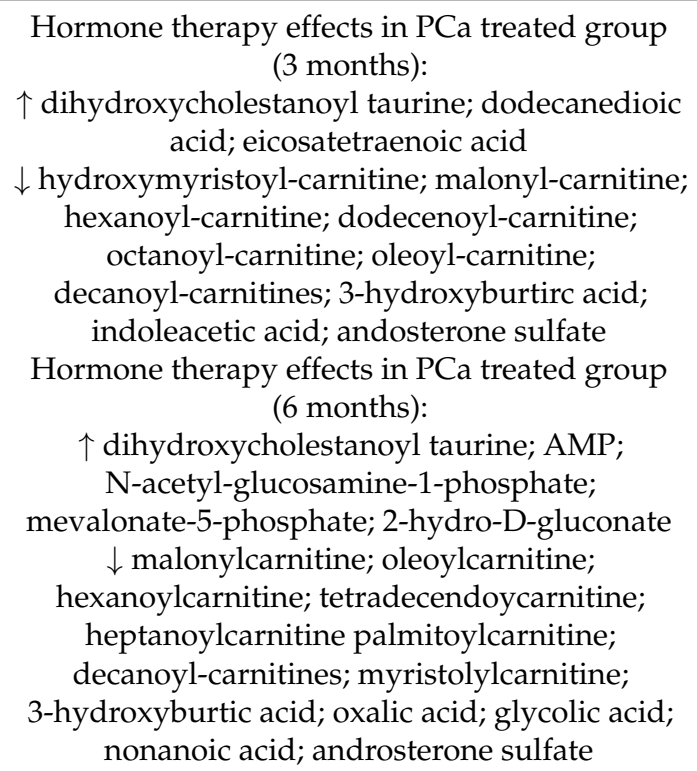 & $\begin{array}{l}\text { Hormone therapy exposure } \\
\text { reduced steroid biosynthesis; } \\
\text { fatty acid } \beta \text {-oxidation and } \\
\text { ketogenesis and alters } \\
\text { microbiome metabolism }\end{array}$ & [87] \\
\hline Hormone therapy & $\begin{array}{c}\text { Tissue extract (polar phase): } \\
\text { BPH group, } n=39 \\
\text { HSPCa group, } n=39 \\
\text { CRPCa group, } n=25\end{array}$ & $\begin{array}{c}{ }^{1} \mathrm{H} \text { NMR } \\
\text { PCA, OPLS-DA } \\
\text { 10-Fold cross validation } \\
\text { CV-ANOVA } \\
\text { Student } t \text {-test } \\
\text { Bonferroni correction } \\
\text { AUC }\end{array}$ & $\begin{array}{l}\text { Hormone therapy resistance effects in CRPCa } \\
\text { (compared with BPH): } \\
\uparrow \text { alanine; lactate; glutamate; taurine } \\
\quad \downarrow \text { myo-inositol; citrate } \\
\text { Hormone therapy resistance effects in CRPCa } \\
\text { (compared with HSPV): } \\
\quad \uparrow \text { creatine } \\
\downarrow \text { choline; lactate; alanine; glutamate; glycine }\end{array}$ & $\begin{array}{l}\text { Castration resistant condition } \\
\text { was associated with } \\
\text { down-regulation of amino } \\
\text { acid metabolism; membrane } \\
\text { metabolism (choline } \\
\text { metabolism) and altered } \\
\text { energy metabolism } \\
\text { (possibility of inverse } \\
\text { Warburg effect) }\end{array}$ & [88] \\
\hline
\end{tabular}


Table 1. Cont.

\begin{tabular}{|c|c|c|c|c|c|}
\hline $\begin{array}{c}\text { Cancer Therapy } \\
\text { under Study }\end{array}$ & Samples & $\begin{array}{l}\text { Instrumental and } \\
\text { Statistical Analysis }\end{array}$ & Treatment Response & $\begin{array}{c}\text { Metabolic } \\
\text { Interpretation }\end{array}$ & Ref. \\
\hline $\begin{array}{l}\text { Chemotherapy: docetaxel } \\
\left(75 \mathrm{mg} / \mathrm{m}^{2}\right) \\
3 \text { weeks of treatment } \\
\text { exposure }\end{array}$ & $\begin{array}{l}\text { Lipophilic plasma extract: } \\
\text { Discovery set: } \\
\text { PCa } \\
\text { untreated group, } n=96 \\
\text { treated group, } n=89 \\
\text { Validation set: } \\
\text { PCa } \\
\text { untreated group, } n=63 \\
\text { treated group, } n=47\end{array}$ & $\begin{array}{l}\text { LC-MS/MS } \\
\text { Latent class analysis } \\
\text { Univariable and } \\
\text { multivariable cox } \\
\text { regression } \\
\text { Logistic regression } \\
\text { Student's } t \text {-test }\end{array}$ & $\begin{array}{l}\text { Docetaxel effects in PCa treated group: } \\
\text { no significant changes were found }\end{array}$ & - & [89] \\
\hline $\begin{array}{l}\text { Chemotherapy (docetaxel) } \\
\text { and hormone therapy (LHRH } \\
\text { analog) } \\
\text { 18-24 weeks of treatment } \\
\text { exposure }\end{array}$ & $\begin{array}{l}\text { Tissue extract (polar phase): } \\
\text { PCa } \\
\text { treated group, } n=12 \\
\text { untreated group, } n=10\end{array}$ & $\begin{array}{c}\text { HPLC } \\
\text { PCA } \\
\text { OPLS-DA } \\
\text { Two-tailed student's } t \text { test } \\
\text { One-way analysis of } \\
\text { variance }\end{array}$ & 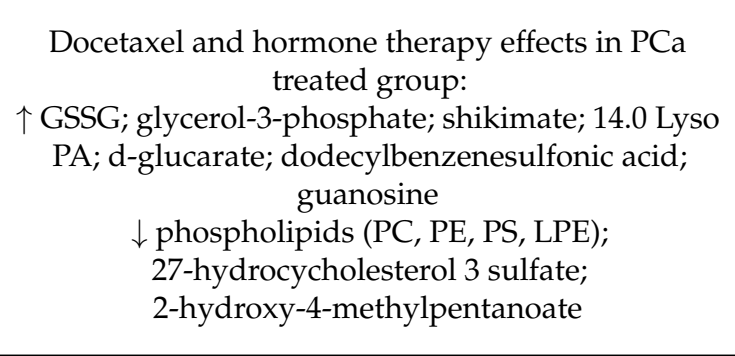 & $\begin{array}{l}\text { Docetaxel and hormone } \\
\text { therapy exposure inhibited } \\
\text { pathways involved in } \\
\text { biosynthesis and energy } \\
\text { metabolism: amino acid } \\
\text { metabolism; purine and } \\
\text { pyrimidine metabolism; TCA } \\
\text { cycle; lipid synthesis; } \\
\text { glutathione metabolism }\end{array}$ & {$[90]$} \\
\hline & $\begin{array}{l}\text { 22RV1: human prostate carcinom } \\
\text { BPH: benign prostatic hyperplasic } \\
\text { isolated from the prostate; GC-MS } \\
\text { oxidized glutathione; HPLC: high- } \\
\text { sensitive PCa; LC-MS/MS: liquid } \\
\text { spectrometry; LC-HRMS: liquid c } \\
\text { prostate; LPE: lysophosphatidyleth } \\
\text { PE: phosphatidylethanolamine; PI } \\
\text { adenocarcinoma of mouse prostate }\end{array}$ & $\begin{array}{l}\text { epithelial cell line; AMP: aden } \\
\text { CRPC: castration resistant PC } \\
\text { gas chromatography-mass spec } \\
\text { erformance liquid chromatogra } \\
\text { hromatography-tandem mass s } \\
\text { romatography-high resolution } \\
\text { nolamine; PA: phosphatidic acid } \\
\text { K: phosphatidylinositol 3-kinas } \\
\text { UMP: uridine monophosphate. }\end{array}$ & $\begin{array}{l}\text { osine monophosphate; AUC: area under curve; AR: andro } \\
\text {; CV-ANOVA: analysis of variance of cross-validated resi } \\
\text { rometry; GC-TOF-MS: gas chromatography-time of flight-n } \\
\text { phy; }{ }^{1} \text { H-NMR: proton nuclear magnetic resonance spectros } \\
\text { ectrometry; LC-HILIC-MS/MS: liquid chromatography-hy } \\
\text { nass spectrometry; LC-MS: liquid chromatography-mass s } \\
\text { PC3: prostate cancer cell line; PC: phosphatidylcholine; PCa } \\
\text {; PS: phosphatidylserine; OPLS-DA: orthogonal partial leas }\end{array}$ & $\begin{array}{l}\text { fen receptor; BCAAs: branched ch } \\
\text { luals; DU145: cell line with epith } \\
\text { ass spectrometry; GSH: reduced gl } \\
\text { opy; HSP90: heat shock protein 90; } \\
\text { lrophilic interaction chromatograp } \\
\text { ectrometry; LNCaP: lymph node } \\
\text { prostate cancer; PCA: principal cor } \\
\text { squares-discriminant analysis; TR }\end{array}$ & $\begin{array}{l}\text { mino acids; } \\
\text { horphology } \\
\text { lone; GSSG: } \\
\text { C: hormone } \\
\text { ndem mass } \\
\text { oma of the } \\
\text { ent analysis; } \\
\text { transgenic }\end{array}$ \\
\hline
\end{tabular}


One of the most recent studies presented in Table 1 was performed by Chi et al. [87] and corroborated the findings reported in the aforementioned study (Saylor et al. [84]). Chi et al. carried out a pharmacometabolomic study with the goal of investigating serum metabolic alterations in PCa patients after hormone therapy at three different time points: before, 3 months, and 6 months after therapy. The most significant changes were found consistently at 3 and 6 months and included significantly lower levels of androsterone sulfate, 3-hydroxybutyric acid, and several long-chain acyl-carnitines, suggesting an impact in steroid synthesis and ketogenesis. Furthermore, some of the known adverse effects of hormone therapy included glucose intolerance and insulin resistance [31,87].

The study carried out by Huang et al. [85] used LC-MS to analyze serum samples from PCa patients with different responses, i.e., good and poor responders, to the combination of bicalutamide and goserelin, which correspond to an antiandrogen and a luteinizing hormone-releasing hormone analog, respectively. Several metabolites were statistically altered between untreated PCa patients and healthy controls, including oxycholic acid, glycochenodeoxycholate, L-tryptophan, docosapentaenoic acid, arachidonic acid, deoxycytidine triphosphate, and pyridinoline. After drug treatment, these metabolites returned to near-normal levels in the good responder patient group, but not in patients who developed castration resistance (poor responders). Additionally, higher levels of docosapentaenoic acid and glycochenodeoxycholate were linked to a faster rate of cholesterol synthesis. These findings may be useful in predicting how patients will respond to this type of hormone therapy combination.

Regarding tissue analysis, Madhu et al. [86] investigated the metabolic effects of degarelix, a hormone blocker, as adjuvant treatment in PCa patients undergoing radical prostatectomy. Polar metabolites were extracted from benign and malignant tissue samples and analyzed by ${ }^{1} \mathrm{H}-\mathrm{NMR}$ spectroscopy. Degarelix treatment induced a significant decrease in the levels of lactate (fuel for oxidative metabolism) and total choline (membrane precursor). These metabolites are usually found to be elevated in PCa human samples [71], so their levels can be monitored and proposed as candidate biomarkers of therapeutic response to degarelix.

A better understanding of the metabolic differences between hormone-sensitive (HSPCa) and castration-resistant PCa (CRPCa) is also of utmost importance. In this way, recent research presented the ${ }^{1} \mathrm{H}$ NMR analysis of tissue from patients with the two phenotypes under hormone therapy [88]. The results showed a good separation between the two groups, with choline, creatine, and lactate as the metabolites with the highest discriminatory power for the metabolic signatures of patients sensitive and resistant to hormone therapy. This potential biomarker panel suggested that the main alterations occurring in the resistant condition were related to alterations in amino acid metabolism, choline metabolism and suggested a possible inverse of the Warburg effect [88].

Lin et al. [89] used LC-MS/MS to investigate changes in plasma metabolites levels in PCa patients before (baseline) and after docetaxel (a chemotherapeutic agent) treatment to develop a tool for monitoring which patients should or should not remain with chemotherapy. However, the authors concluded that it was not possible to assign a metabolic signature that distinguishes between the two groups of patients. The authors justified the findings by pointing out important limitations in the study that may have contributed to the results; namely, the inability to identify the circulant lipid species and the small number of patients enrolled, which remains a limiting and dependent factor in studies using human samples. Notwithstanding, a recent study using the combination of docetaxel with a luteinizing hormone-releasing hormone analog (hormone therapy) before prostatectomy addressed the impact of this adjuvant combination on the metabolome of PCa tissue samples [90]. The results unveiled significant dysregulations in the levels of several metabolites including an increase in the levels of glycerol-3-phosphate, dodecylbenzenesulfonic acid, guanosine, among others, and a decrease in the levels of phospholipids, 27-hydroxycholesterol 3 sulfate, 2-hydroxy-4-methylpentanoate, among others. Since most of these metabolites belong to important pathways for cell growth and proliferation, such as biosynthesis and en- 
ergy metabolism, the use of this type of combination before prostatectomy suggested a therapeutic benefit limiting tumor growth. Expression of key proteins in tumor samples from patients receiving or not receiving the neoadjuvant therapy was also evaluated to corroborate the findings obtained by HPLC analysis.

\subsection{Pharmacometabolomic Studies in Bladder Cancer}

Regarding BCa, Table 2 depicts the three pharmacometabolomic studies performed in the last 10 years including the methodology used and a summary of the main findings. Two in vitro pharmacometabolomic studies [13,92] were conducted to address the metabolic implications of cisplatin resistance and one additional study was performed to predict the response to gemcitabine as neoadjuvant therapy [93].

Although BCa tumors are initially susceptible to cisplatin, the development of resistance during treatment hampers its efficacy. In this regard, Lee et al. [13] performed a comparative lipidomic profiling of two BCa cell lines: a cisplatin-sensitive and a cisplatinresistant cell line as a representation of in vivo chemoresistant BCa. Ultra-performance LC-MS (UPLC-MS) profiling of several lipid species revealed altered levels between the endometabolome of the two cell lines, including significantly elevated levels of one ceramide and two triglycerides in cisplatin-resistant cells. Ceramides are recognized as important elements in cellular membrane structure, whereas triglycerides are essential for energy storage [71], which reinforces the maintenance of cell growth to promote tumor progression on a resistance condition [13]. The authors concluded that a rearrangement of lipid metabolism is required for $\mathrm{BCa}$ pathogenesis.

The same in vitro model (resistant, T24R, and cisplatin sensitive cell lines, T24S) was explored by Wen et al. [92] that performed an NMR quantitative analysis of glucosederived metabolites in cisplatin-resistant conditions. In comparison to sensitive cells, resistant cells consumed more glucose and consequently excreted more glucose-derivatives, acetate, and fatty acids. The authors also found a preference for glucose as a source of increased fatty acid synthesis in resistant cells by using labeled glucose. These findings agree with the previous study [13] confirming a reprogramming of lipid metabolism in cisplatin-resistant BCa.

The combination of gemcitabine and cisplatin is frequently recommended in $\mathrm{BCa}$ treatment. A study performed by Yang et al. [93] aimed to identify predictive biomarkers of efficacy to treatment with gemcitabine as neoadjuvant therapy for transurethral resection of bladder tumors. Metabolite analysis using high-resolution LC-MS was performed on tissue collected from BCa patients before and after submucosal gemcitabine injection. Adjacent healthy tissue was also collected for comparison with normal conditions. Tissue metabolic profiling unveiled significant alterations in the levels of several metabolites, most notably alterations on bilirubin and retinal, which recovered to near normal levels after gemcitabine treatment. The authors proposed that bilirubin and retinal could be investigated as therapeutic targets of gemcitabine.

\subsection{Pharmacometabolomic Studies in Renal Cell Carcinoma}

Sunitinib is commonly used for the treatment of advanced RCC, but $30 \%$ of patients are intrinsically resistant to this type of targeted agent [12]. In this regard, two studies were carried out with the goal of identifying biomarkers of resistance to sunitinib treatment using in vitro [83] and xenograft [94] models, and three others investigated the metabolic responses in human samples after exposure to different anti-neoplastic agents [95-97]. Therapeutic strategies for resistance situations are of utmost importance, particularly in the case of RCC, for which the systemic therapy effectiveness rates remain low. Table 3 lists five pharmacometabolomic studies focused on RCC therapeutics performed in the last 10 years, including the methodology used and a summary of the main findings. 
Table 2. Pharmacometabolomic studies performed in BCa.

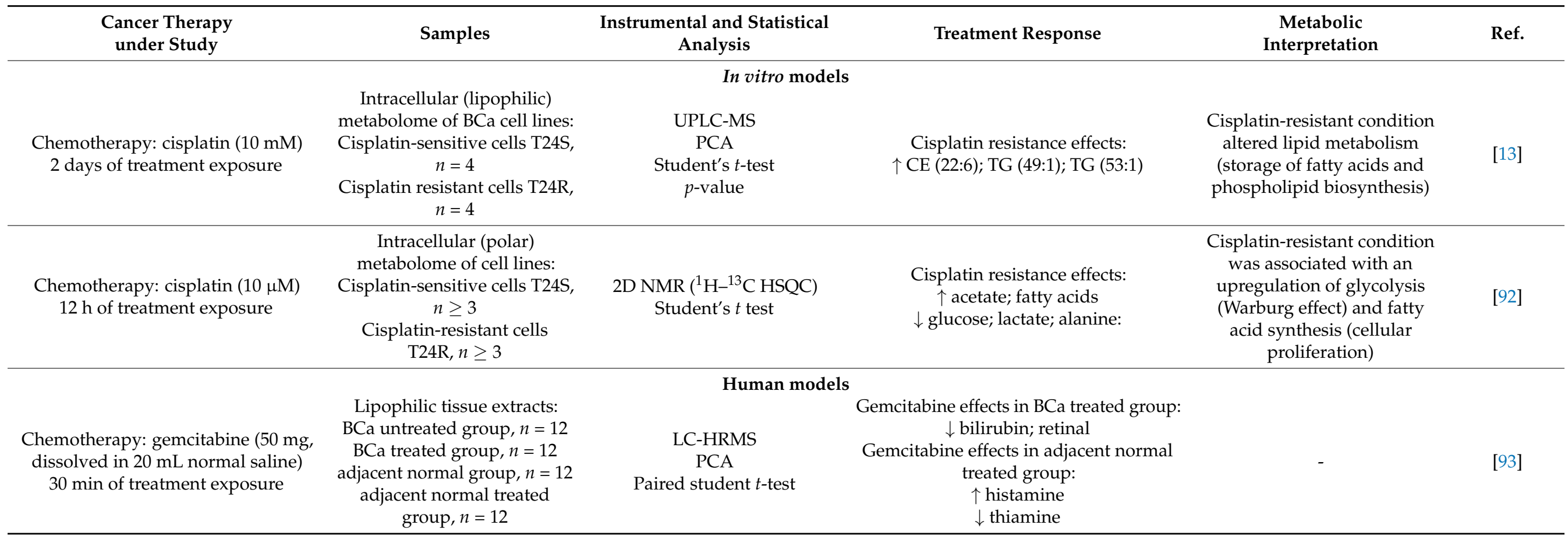

2D NMR: two-dimensional nuclear magnetic resonance; ${ }^{1} \mathrm{H}-13 \mathrm{C}$ HSOC: ${ }^{1} \mathrm{H}-13 \mathrm{C}$ heteronuclear single quantum coherence; BCa: bladder cancer. CE: ceramides; LC-MS/MS: liquid chromatography-tandem mass spectrometry; LC-HRMS: Liquid chromatography-high resolution mass spectrometry; LC-MS: liquid chromatography-mass spectrometry; PCA: principal component analysis; T24: human urinary bladder cancer patient cell line; TG: triglycerides; UPLC-MS: ultraperformance liquid chromatography-tandem mass spectrometry. 
Table 3. Pharmacometabolomic studies performed in RCC.

\begin{tabular}{|c|c|c|c|c|c|}
\hline $\begin{array}{l}\text { Cancer Therapy } \\
\text { under Study }\end{array}$ & Samples & $\begin{array}{c}\text { Instrumental and Statistical } \\
\text { Analysis }\end{array}$ & Treatment Response & $\begin{array}{c}\text { Biological } \\
\text { Interpretation }\end{array}$ & Ref. \\
\hline $\begin{array}{l}\text { Targeted therapy: sunitinib }(10 \mathrm{mM}) \\
5 \text { days of treatment exposure }\end{array}$ & $\begin{array}{l}\text { Intracellular (polar) metabolome } \\
\text { of RCC cell lines: } \\
\text { 786-O Par (parental), } n=3 \\
\text { 786-O Res (sunitinib-resistant), } \\
n=3\end{array}$ & $\begin{array}{c}\text { CE-TOF MS } \\
\text { PCA } \\
\text { Fold change } \\
\text { Two-tailed student t-test }\end{array}$ & $\begin{array}{l}\text { els } \\
\text { Sunitinib resistance effects: } \\
\uparrow \text { dihydroxyacetone phosphate; fructose } \\
\text { 1,6-bisphosphate; choline; cysteine; } \\
\text { methionine; thymidine; citrate; } \\
\text { glycerophosphorate; fumarate; } \\
\text { glucose-6-phosphate; tryptophan; ADP; } \\
\text { creatine; 6-phosphogluconate; } \\
\text { sedoheptulose-7-phosphate; } \\
\text { fructose-6-phosphate; glutamate; malic } \\
\text { acid; acetyl-CoA } \\
\downarrow \text { oxidized glutathione; ornithine; } \\
\text { creatinine; guanine; succinic acid }\end{array}$ & $\begin{array}{l}\text { Sunitinib resistant condition } \\
\text { is associated with } \\
\text { up-regulation on lipid } \\
\text { biosynthesis (membrane } \\
\text { metabolism), energy } \\
\text { metabolism (glycolysis and } \\
\text { TCA cycle), arginine and } \\
\text { proline pathways, urea cycle } \\
\text { and nucleic acid biosynthesis }\end{array}$ & [83] \\
\hline $\begin{array}{l}\text { Target therapy: sunitinib ( } 25 \mathrm{mg} / \mathrm{kg} \\
\text { per day) } \\
4 \text { weeks of treatment exposure }\end{array}$ & $\begin{array}{c}\text { Intracellular (lipophilic) } \\
\text { metabolome of primary cell } \\
\text { culture of xenograft RCC mouse } \\
\text { model: } \\
\text { 786-P (parental) } \\
\text { untreated, } n=5 \\
\text { treated, } n=5 \\
\text { 786-R (sunitinib-resistant) } \\
\text { treated, } n=5\end{array}$ & $\begin{array}{c}\text { LC-MS/MS } \\
\text { Mann-Whitney U test } \\
\text { One-way ANOVA Post hoc } \\
\text { Tukey's test }\end{array}$ & $\begin{array}{c}\text { Sunitinib resistance effects in 786-R } \\
\text { (compared with 786-P treated): } \\
\uparrow \text { glutamine; 2-oxoglutaric acid; fructose } \\
\text { 6-phosohate; D-sedoheptulose } \\
\text { 7-phosphate; glucose 1-phosphate; } \\
\text { myo-inositol } \\
\text { Sunitinib resistance effects in 786-R } \\
\text { (compared with 786-P untreated) } \\
\text { 1-phosphate; fructose 6-phosohate; } \\
\text { D-sedoheptulose 7-phosphate } \\
\downarrow \text { glutamate; glutathione; myo-inositol }\end{array}$ & $\begin{array}{l}\text { Sunitinib resistant condition } \\
\text { is associated with } \\
\text { up-regulation of energy } \\
\text { metabolism (glutamine } \\
\text { uptake, glycolysis, and TCA } \\
\text { cycle) and antioxidant } \\
\text { activity }\end{array}$ & [94] \\
\hline
\end{tabular}


Table 3. Cont.

\begin{tabular}{|c|c|c|c|c|c|}
\hline $\begin{array}{l}\text { Cancer Therapy } \\
\text { under Study }\end{array}$ & Samples & $\begin{array}{c}\text { Instrumental and Statistical } \\
\text { Analysis }\end{array}$ & Treatment Response & $\begin{array}{c}\text { Biological } \\
\text { Interpretation }\end{array}$ & Ref. \\
\hline $\begin{array}{c}\text { Targeted therapy: } \\
\text { Arm A- bevacizumab ( } 10 \mathrm{mg} / \mathrm{kg} 1 \\
\text { every } 2 \text { weeks) and temsirolimus } \\
\text { ( } 25 \mathrm{mg} \text { per week) combination } \\
\text { Arm B-sunitinib ( } 50 \mathrm{mg} \text { per day for } \\
4 \text { weeks followed by } 2 \text { weeks off }) \\
\text { Arm C- interferon- } \alpha \text { ( } 9 \text { mIU three } \\
\text { times per week) and bevacizumab } \\
\text { (10 mg/ kg every } 2 \text { weeks) } \\
\text { combination } \\
2 \text { and } 5-6 \text { weeks of treatment } \\
\text { exposure }\end{array}$ & $\begin{array}{c}\text { Hydrophilic serum extracts: } \\
\text { Arm A } \\
\text { RCC } \\
\text { untreated group, } n=56 \\
\text { treated group ( } 2 \text { weeks), } n=55 \\
\text { treated group (5-6 weeks), } n=49 \\
\text { Arm B } \\
\text { RCC } \\
\text { untreated group, } n=26 \\
\text { treated group (2 weeks), n=22 } \\
\text { treated group (5-6 weeks), } n=20 \\
\text { Arm C } \\
\text { RCC } \\
\text { untreated group, } n=20 \\
\text { treated group (2 weeks), } n=25 \\
\text { treated group (5-6 weeks), } n=22\end{array}$ & $\begin{array}{c}{ }^{1} \mathrm{H} \text { NMR } \\
\text { PCA } \\
\text { OPLS } \\
\text { Cross-validation ANOVA }\end{array}$ & $\begin{array}{c}\text { Bevacizumab and temsirolimus } \\
\text { combination effects in RCC treated } \\
\text { group ( } 2 \text { weeks): } \\
\uparrow \text { glycerol backbone of } \\
\text { phosphoglycerides; triacylglycerides; } \\
\text { fatty acids; very low-density lipoproteins } \\
\text { and low-density lipoproteins; glucose; } \\
\text { N-acetylglycoproteins } \\
\text { Bevacizumab and temsirolimus } \\
\text { combination effects in RCC treated } \\
\text { group (5-6 weeks): } \\
\uparrow \text { glycerol backbone of } \\
\text { phosphoglycerides; triacylglycerides } \\
\text { fatty acids; very low-density } \\
\text { lipoproteins; low-density lipoproteins; } \\
\text { glucose; N-acetylglycoproteins; BCAAs; } \\
\text { alanine; glycine; glutamine; acetoacetate; } \\
\text { acetone; glycerol; cholesterol } \\
\downarrow \text { acetate; ethanol } \\
\text { Sunitinib effects in RCC treated group (2 } \\
\text { and 5-6 weeks): no significant changes } \\
\text { were found } \\
\text { Interferon- } \alpha \text { and bevacizumab } \\
\text { combination effects in RCC treated } \\
\text { group (5-6 weeks): } \\
\uparrow \text { lipids and very low-density } \\
\text { lipoproteins } \\
\downarrow \text { low-density lipoproteins }\end{array}$ & $\begin{array}{c}\text { Bevacizumab and } \\
\text { temsirolimus combination } \\
\text { caused the greatest } \\
\text { modification essentially in } \\
\text { lipid and lipoprotein } \\
\text { metabolisms }\end{array}$ & [96] \\
\hline
\end{tabular}


Table 3. Cont.

\begin{tabular}{|c|c|c|c|c|c|}
\hline $\begin{array}{c}\text { Cancer Therapy } \\
\text { under Study }\end{array}$ & Samples & $\begin{array}{c}\text { Instrumental and Statistical } \\
\text { Analysis }\end{array}$ & Treatment Response & $\begin{array}{c}\text { Biological } \\
\text { Interpretation }\end{array}$ & Ref. \\
\hline $\begin{array}{c}\text { Immunotherapy: } \\
\text { Arm A- nivolumab (phase } 1: \\
0.3 / 3 / 10 \mathrm{mg} / \mathrm{kg} \text { every } 3 \text { weeks; } \\
\text { phase } 3: 3 \mathrm{mg} / \mathrm{kg} \text { every } 2 \text { weeks) } \\
\text { Arm B- everolimus phase } 3 \\
\text { (10 mg per day) } \\
4 \text { and } 8 \text { weeks of treatment exposure }\end{array}$ & $\begin{array}{c}\text { Lipophilic serum extracts: } \\
\text { Arm A } \\
\text { Phase } 1 \text { trial } \\
\text { RCC } \\
\text { untreated group, } n=91 \\
\text { treated group ( } 4 \text { weeks), } n=84 \\
\text { treated group ( } 9 \text { weeks), } n=69 \\
\text { Phase } 3 \text { trial } \\
\text { RCC } \\
\text { untreated group, } n=392 \\
\text { treated group ( } 4 \text { weeks), } n=98 \\
\text { treated group ( } 8 \text { weeks), } n=324 \\
\text { Arm B } \\
\text { RCC } \\
\text { untreated group, } n=349 \\
\text { treated group ( } 4 \text { weeks), } n=58 \\
\text { treated group (8 weeks), } n=0\end{array}$ & $\begin{array}{c}\text { CC-MS } \\
\text { LC } \\
\text { Volcano plots } \\
\text { Benjamin-Hochberg multiple } \\
\text { testing corrections } \\
\text { Pearson correlations }\end{array}$ & $\begin{array}{l}\text { Nivolumab effects in RCC treated group } \\
\text { (phase } 1 \text { and } 3 \text { ): } \\
\uparrow \text { kynurenine } \\
\text { Everolimus effects in RCC treated group: } \\
\text { no significant changes were found }\end{array}$ & $\begin{array}{l}\text { Nivolumab exposure } \\
\text { upregulated tryptophan } \\
\text { catabolism (increased } \\
\text { tryptophan to kynurenine } \\
\text { conversion) resulting in an } \\
\text { adaptive immune } \\
\text { suppressive } \\
\text { microenvironment }\end{array}$ & [97] \\
\hline
\end{tabular}

786-O: hypertriploid renal cell carcinoma cell line; ${ }^{1} \mathrm{H}$ NMR: proton nuclear magnetic resonance; CE: ceramide; CE-TOF MS: capillary electrophoresis-time of flight mass spectrometry; LC-MS: liquid chromatography-mass spectrometry; LC-MS/MS: liquid chromatography-tandem mass spectrometry; OPLS: orthogonal partial least squares; PCA: principal component analysis; PC: phosphocholine; RCC: renal cell carcinoma; SM: sphingomyelin. 
The first study used capillary electrophoresis-time of flight mass spectrometry (CE-MS) to look at metabolic changes in sunitinib-resistant RCC cells [83]. The results revealed that intracellular levels of several metabolites involved in energy processes, including glycolysis, TCA cycle, and pentose phosphate pathway, were found to be higher in sunitinib-resistant cell lines [83]. Because glycolysis is the primary source of energy in this type of cancer cells, these mechanisms are essential for RCC progression [98]. These findings are consistent with a most recent study performed by Sato et al. [94] where the use of a xenograft RCC mouse model was reported to identify changes in intracellular metabolites unveiling the mechanisms of sunitinib resistance. In brief, they subcutaneously implanted both sensitive (786-P) and sunitinib-resistant (786-R) cell lines in different mice groups followed by administration of sunitinib. After 4 weeks of sunitinib exposure, tumoral tissues were collected from each mouse and subjected to primary cell culture. In the sunitinib-resistant condition, LC-MS analysis revealed significantly increased intracellular levels of fructose 6-phosphate, D-sedoheptulose 7-phosphate, and glucose 1-phosphate, suggesting a higher glycolysis rate together with a higher uptake of glutamine into the TCA cycle. These results were corroborated by the higher expression of glutamine transporters in sunitinib-resistant cells. Moreover, the results disclosed significantly higher levels of glutathione and myoinositol in resistant primary cells compared to sensitive cells, indicating a higher antioxidant activity in resistant cells as a protective action against the antitumor effects of sunitinib. Future validation of the role of these pathways using sensitive and sunitinib-resistant RCC patient groups may identify early biomarkers of resistance.

The implications of sunitinib and other targeted therapies on the metabolism of patients with metastatic RCC were also investigated by Jobard et al. [96]. Pre-treatment and serial on-treatment serum samples were collected during a clinical trial and analyzed by NMR spectroscopy. The main goal of this study was to compare the metabolic response to two conventional treatments (sunitinib and interferon- $\alpha$ in combination with bevacizumab) with a new combination with bevacizumab, an anti-angiogenic drug, and temsirolimus, an mTOR inhibitor, proving the use of a pharmacometabolic approach to monitor and predict responses. The combination of bevacizumab and temsirolimus caused a faster and higher impact on the metabolome of treated RCC patients when compared to other treatments. The main dysregulated metabolites were lipid species and lipoproteins, which are metabolites responsible for the transport of endogenous lipids and cholesterol, metabolites of $\beta$-oxidation, as well as glucose, cholesterol, among others. These findings could be indicative of the associated side effects of this combination, as some toxic effects, such as hypercholesteremia and hypertriglyceridemia, have already been observed in RCC patients under temsirolimus treatment [99]. These results highlighted the potential of a pharmacometabolomics approach to predict chemotherapeutic side effects [96].

The pharmacometabolomic studies performed by Li et al. [97] and Mock et al. [95] investigated the impact of immunotherapy. The first study [97] used LC-MS to analyze serum samples collected from different RCC patients (at 4 and 8 weeks of treatment). The profiling of serum metabolites revealed an increase in the kynurenine/tryptophan ratio. Kynurenine is a product from tryptophan metabolism that causes immunosuppression. Tryptophan is usually found downregulated in RCC cells suggesting an increased use by these cells [100]. In this study, the alteration in the kynurenine/tryptophan ratio was associated with an adaptative resistance mechanism and, as a result, a worse overall survival of RCC patients. The monitoring of these metabolites can provide information about the patient's condition during treatment.

Lastly, the study performed by Mock et al. [95] investigated the metabolic changes that underpin immunotherapy response and failure. To achieve this goal, serum samples from 28 urological cancer patients (25 RCC plus 2 BCa plus 1 patient diagnosed with both) who underwent immunotherapy were collected before the first, second, and third cycles, followed by LC-MS analysis. Most serum metabolites associated with response to immunotherapy belong to the class of very long-chain fatty acid-containing lipids (VLCFA-containing lipids). Comparing the serum lipid content between responders and 
non-responders among the first and third cycles, VLCFA-containing lipids seem to act as sensitizers to immune treatment, based on the impact of T cell metabolism, as suggested by the authors. The prognostic value of the VLCFA-containing lipids was also investigated by transcriptomic analysis. To confirm the potential of this metabolite class in predicting immunotherapy response, the obtained results must be validated in a larger patient cohort.

\section{Conclusions and Future Perspectives}

Despite the efforts made to date to improve cancer therapies, the selection of the best treatment modality for metastatic stages in urological cancers remains a challenge. Thus, the understanding of the impact of treatments on the metabolome of patients can be paramount for predicting therapeutic responses in the personalized medicine era. The studies published so far on this topic advanced with metabolic signatures characteristic of responses to hormone therapy and chemotherapy in PCa, along with chemotherapy in $\mathrm{BCa}$ and targeted therapy and immunotherapy in RCC. These metabolic signatures may lead to the definition of candidate predictive biomarkers of treatment response, as well as the recognition of metabolic alterations that occur during resistance development.

Further studies are needed to validate the impact of the different treatments on the metabolic fingerprint in larger and independent clinical cohorts of different populations (e.g., ethnicities) of urological cancers patients, as well as to complement those studies with multi-omics analyses to improve accuracy in predictive biomarker detection and a better understanding of the mechanisms underlying cancer therapeutic resistance. In this regard, a better stratification of patients based on their metabotypes (metabolic signatures) may help to predict its prognosis. In future pharmacometabolomics studies, it is important to consider the standardization of protocols of sample handling and storage, analytical conditions, and data interpretation. Human sample biobanks are an important aspect to consider in these studies because they preserve samples collected before and during a treatment regimen, increasing the availability of a higher number of human samples. Additionally, the incorporation of machine learning techniques can speed up the interpretation of big data generated in clinical practice by recognizing patterns of metabotypes to improve patient stratification and, as a result, devising optimal treatment strategies.

Author Contributions: Conceptualization, M.C., M.d.L.B., P.G.d.P. and J.P.; literature search, F.A. and J.P.; writing—original draft preparation, F.A.; writing—review and editing, M.C., M.d.L.B., P.G.d.P. and J.P. All authors have read and agreed to the published version of the manuscript.

Funding: This research was funded by national funds from FCT-Fundação para a Ciência e a Tecnologia, I.P., in the scope of the project UIDP/04378/2020 and UIDB/04378/2020 of the Research Unit on Applied Molecular Biosciences-UCIBIO, and the project LA/P/0140/2020 of the Associate Laboratory Institute for Health and Bioeconomy-i4HB. F.A. thanks FCT for the PhD grant (UI/BD/151313/2021).

Institutional Review Board Statement: Not applicable.

Informed Consent Statement: Not applicable.

Data Availability Statement: Not applicable.

Conflicts of Interest: The authors declare no conflict of interest.

\section{References}

1. Ferlay, J.; Wild, C.P.; Bray, F. The burden of cancer worldwide: Current and future perspectives. Holland-Frei Cancer Med. 2016, 1-15. [CrossRef]

2. Sung, H.; Ferlay, J.; Siegel, R.L.; Laversanne, M.; Soerjomataram, I.; Jemal, A.; Bray, F. Global cancer statistics 2020: GLOBOCAN estimates of incidence and mortality worldwide for 36 cancers in 185 countries. CA Cancer J. Clin. 2021, 71, 209-249. [CrossRef]

3. Bray, F.; Ferlay, J.; Soerjomataram, I.; Siegel, R.L.; Torre, L.A.; Jemal, A. Global cancer statistics 2018: GLOBOCAN estimates of incidence and mortality worldwide for 36 cancers in 185 countries. CA Cancer J. Clin. 2018, 68, 394-424. [CrossRef] [PubMed]

4. Siegel, R.L.; Miller, K.D.; Fuchs, H.E.; Jemal, A. Cancer Statistics, 2021. CA Cancer J. Clin. 2021, 71, 7-33. [CrossRef]

5. Cheville, J.C.; Lohse, C.M.; Zincke, H.; Weaver, A.L.; Blute, M.L. Comparisons of outcome and prognostic features among histologic subtypes of renal cell carcinoma. Am. J. Surg. Pathol. 2003, 27, 612-624. [CrossRef] [PubMed] 
6. Muglia, V.F.; Prando, A. Renal cell carcinoma: Histological classification and correlation with imaging findings. Radiol. Bras. 2015, 48, 166-174. [CrossRef] [PubMed]

7. Escudier, B.; Porta, C.; Schmidinger, M.; Rioux-Leclercq, N.; Bex, A.; Khoo, V.; Grunwald, V.; Gillessen, S.; Horwich, A. Renal cell carcinoma: ESMO Clinical practice guidelines for diagnosis, treatment and follow-updagger. Ann. Oncol. 2019, 30, 706-720. [CrossRef] [PubMed]

8. Khatami, F.; Hassanzad, M.; Nikfar, S.; Guitynavard, F.; Karimaee, S.; Tamehri Zadeh, S.S.; Gholami, K.; Rezaeian, A.; Feiz-Abadi, S.A.; Jahanshahi, F. The importance of personalized medicine in urological cancers. J. Diabetes Metab. Disord. 2021, 1-12. [CrossRef]

9. Abbas, Z.; Rehman, S. An overview of cancer treatment modalities. In Neoplasm; IntechOpen: London, UK, 2018; Volume 1, pp. 139-157. [CrossRef]

10. Lee, D.H. Practical issues of biomarker-assisted targeted therapy in precision medicine and immuno-oncology era. ESMO Open 2018, 3, 370. [CrossRef]

11. Chandrasekar, T.; Yang, J.C.; Gao, A.C.; Evans, C.P. Mechanisms of resistance in castration-resistant prostate cancer (CRPC). Transl. Androl. Urol. 2015, 4, 365-380. [CrossRef]

12. Morais, C. Sunitinib resistance in renal cell carcinoma. J. Kidney Cancer VHL 2014, 1, 1-11. [CrossRef] [PubMed]

13. Lee, M.Y.; Yeon, A.; Shahid, M.; Cho, E.; Sairam, V.; Figlin, R.; Kim, K.H.; Kim, J. Reprogrammed lipid metabolism in bladder cancer with cisplatin resistance. Oncotarget 2018, 9, 13231-13243. [CrossRef] [PubMed]

14. Vinay, D.S.; Ryan, E.P.; Pawelec, G.; Talib, W.H.; Stagg, J.; Elkord, E.; Lichtor, T.; Decker, W.K.; Whelan, R.L.; Kumara, H.; et al. Immune evasion in cancer: Mechanistic basis and therapeutic strategies. Semin. Cancer Biol. 2015, 35, 185-198. [CrossRef] [PubMed]

15. Mellman, I.; Coukos, G.; Dranoff, G. Cancer immunotherapy comes of age. Nature 2011, 480, 480-489. [CrossRef]

16. Popova, A.A.; Levkin, P.A. Precision medicine in oncology: In vitro drug sensitivity and resistance test (DSRT) for selection of personalized anticancer therapy. Adv. Ther. 2020, 3, 1900100. [CrossRef]

17. Marson, F.A.L.; Bertuzzo, C.S.; Ribeiro, J.D. Personalized or precision medicine? the example of cystic fibrosis. Front. Pharmacol. 2017, 8, 390. [CrossRef] [PubMed]

18. Unger, F.T.; Witte, I.; David, K.A. Prediction of individual response to anticancer therapy: Historical and future perspectives. Cell. Mol. Life. Sci. 2015, 72, 729-757. [CrossRef] [PubMed]

19. Gardner, S.; Das, S.; Taylor, K. AI enabled precision medicine: Patient stratification, drug repurposing and combination therapies. In Artificial Intelligence in Oncology Drug Discovery and Development; IntechOpen: London, UK, 2020. [CrossRef]

20. Kohler, S. Precision medicine-Moving away from one-size-fits-all. Quest 2018, 14, 12-15.

21. Ventola, C.L. Role of pharmacogenomic biomarkers in predicting and improving drug response: Part 1: The clinical significance of pharmacogenetic variants. Pharm. Ther. 2013, 38, 545.

22. Beger, R.D.; Schmidt, M.A.; Kaddurah-Daouk, R. Current concepts in pharmacometabolomics, biomarker discovery, and precision medicine. Metabolites 2020, 10, 129. [CrossRef]

23. Emwas, A.; Szczepski, K.; McKay, R.T.; Asfour, H.; Chang, C.; Lachowicz, J.; Jaremko, M. Pharmacometabolomics: A new horizon in personalized medicine. In Metabolomics; IntechOpen: London, UK, 2021. [CrossRef]

24. Terris, M.K. Metastatic and Advanced Prostate Cancer. Available online: https://emedicine.medscape.com/article/454114 -overview\#a1 (accessed on 1 December 2021).

25. Parker, C.; Castro, E.; Fizazi, K.; Heidenreich, A.; Ost, P.; Procopio, G.; Tombal, B.; Gillessen, S. Prostate cancer: ESMO Clinical practice guidelines for diagnosis, treatment and follow-up. Ann. Oncol. 2020, 31, 1119-1134. [CrossRef] [PubMed]

26. Crawford, E.D.; Petrylak, D.P.; Shore, N.; Saad, F.; Slovin, S.F.; Vogelzang, N.J.; Keane, T.E.; Koo, P.J.; Gomella, L.G.; O’Sullivan, J.M.; et al. The role of therapeutic layering in optimizing treatment for patients with castration-resistant prostate cancer (prostate cancer radiographic assessments for detection of advanced recurrence II). Urology 2017, 104, 150-159. [CrossRef] [PubMed]

27. Nuhn, P.; De Bono, J.S.; Fizazi, K.; Freedland, S.J.; Grilli, M.; Kantoff, P.W.; Sonpavde, G.; Sternberg, C.N.; Yegnasubramanian, S.; Antonarakis, E.S. Update on systemic prostate cancer therapies: Management of metastatic castration-resistant prostate cancer in the era of precision oncology. Eur. Urol. 2019, 75, 88-99. [CrossRef] [PubMed]

28. American Cancer Society. Survival Rates for Prostate Cancer. Available online: https://www.cancer.org/cancer/prostate-cancer/ detection-diagnosisstaging/survival-rates.html (accessed on 1 December 2021).

29. Siddiqui, Z.A.; Krauss, D.J. Adjuvant androgen deprivation therapy for prostate cancer treated with radiation therapy. Transl. Androl. Urol. 2018, 7, 378-389. [CrossRef]

30. Connolly, R.M.; Carducci, M.A.; Antonarakis, E.S. Use of androgen deprivation therapy in prostate cancer: Indications and prevalence. Asian J. Androl. 2012, 14, 177-186. [CrossRef]

31. Ahmadi, H.; Daneshmand, S. Androgen deprivation therapy: Evidence-based management of side effects. BJU Int. 2013, 111, 543-548. [CrossRef]

32. Adamaki, M.; Zoumpourlis, V. Immunotherapy as a precision medicine tool for the treatment of prostate cancer. Cancers 2021, 13, 173. [CrossRef]

33. Teyssonneau, D.; Margot, H.; Cabart, M.; Anonnay, M.; Sargos, P.; Vuong, N.S.; Soubeyran, I.; Sevenet, N.; Roubaud, G. Prostate cancer and PARP inhibitors: Progress and challenges. J. Hematol. Oncol. 2021, 14, 51. [CrossRef]

34. $\mathrm{Wu}$, J.; Lu, L.Y.; Yu, X. The role of BRCA1 in DNA damage response. Protein Cell 2010, 1, 117-123. [CrossRef] 
35. Wang, F.; Li, Z.; Feng, X.; Yang, D.; Lin, M. Advances in PSMA-targeted therapy for prostate cancer. Prostate Cancer Prostatic Dis. 2021, 1-16. [CrossRef]

36. Vanneman, M.; Dranoff, G. Combining immunotherapy and targeted therapies in cancer treatment. Nat. Rev. Cancer 2012, 12, 237-251. [CrossRef]

37. Chalasani, V.; Chin, J.L.; Izawa, J.I. Histologic variants of urothelial bladder cancer and nonurothelial histology in bladder cancer. Can. Urol. Assoc. J. 2009, 3, 193-198. [CrossRef]

38. Bellmunt, J.; Orsola, A.; Leow, J.J.; Wiegel, T.; De Santis, M.; Horwich, A.; Group, E.G.W. Bladder cancer: ESMO practice guidelines for diagnosis, treatment and follow-up. Ann. Oncol. 2014, 25 (Suppl. 3), 40-48. [CrossRef] [PubMed]

39. Patel, V.G.; Oh, W.K.; Galsky, M.D. Treatment of muscle-invasive and advanced bladder cancer in 2020. CA Cancer J. Clin. 2020, 70, 404-423. [CrossRef]

40. De George, K.C.; Holt, H.R.; Hodges, S.C. Bladder cancer: Diagnosis and treatment. Am. Fam. Physician 2017, 96, 507-514.

41. Kacew, A.; Sweis, R.F. FGFR3 Alterations in the era of immunotherapy for urothelial bladder cancer. Front. Immunol. 2020, 11, 575258. [CrossRef] [PubMed]

42. Tural, D.; Selcukbiricik, F.; Olmez, O.F.; Sumbul, A.T.; Erman, M.; Coskun, H.S.; Artac, M.; Kilickap, S. Response to first-line chemotherapy regimen is associated with efficacy of immune checkpoint blockade therapies in patients with metastatic urothelial carcinoma. Int. J. Clin. Oncol. 2021, 27, 585-591. [CrossRef] [PubMed]

43. Bankhead, C. Two FDA wins for Immunotherapy in Bladder Cancer. Available online: https://www.medpagetoday.com/ hematologyoncology/othercancers/92337 (accessed on 6 December 2021).

44. Montazeri, K.; Bellmunt, J. Erdafitinib for the treatment of metastatic bladder cancer. Expert Rev. Clin. Pharmacol. 2020, 13, 1-6. [CrossRef] [PubMed]

45. Ross, J.S.; Wang, K.; Al-Rohil, R.N.; Nazeer, T.; Sheehan, C.E.; Otto, G.A.; He, J.; Palmer, G.; Yelensky, R.; Lipson, D.; et al. Advanced urothelial carcinoma: Next-generation sequencing reveals diverse genomic alterations and targets of therapy. Mod. Pathol. 2014, 27, 271-280. [CrossRef]

46. Weiss, R.H. Metabolomics and metabolic reprogramming in kidney cancer. Semin. Nephrol. 2018, 38, 175-182. [CrossRef]

47. Ciccarese, C.; Brunelli, M.; Montironi, R.; Fiorentino, M.; Iacovelli, R.; Heng, D.; Tortora, G.; Massari, F. The prospect of precision therapy for renal cell carcinoma. Cancer Treat. Rev. 2016, 49, 37-44. [CrossRef]

48. Manley, B.J.; Hakimi, A.A. Molecular profiling of renal cell carcinoma: Building a bridge toward clinical impact. Curr. Opin. Urol. 2016, 26, 383-387. [CrossRef]

49. Padala, S.A.; Barsouk, A.; Thandra, K.C.; Saginala, K.; Mohammed, A.; Vakiti, A.; Rawla, P.; Barsouk, A. Epidemiology of renal cell carcinoma. World J. Oncol. 2020, 11, 79-87. [CrossRef] [PubMed]

50. American Society of Clinical Oncology. Kidney Cancer: Statistics. Available online: https://www.cancer.net/cancer-types/ kidney-cancer/statistics (accessed on 6 December 2021).

51. American Cancer Society. Kidney Cancer Treatment. Available online: https://www.cancer.org/cancer/kidney-cancer/treating. html (accessed on 6 December 2021).

52. Kapoor, A. First-line treatment options in metastatic renal cell cancer. Can. Urol. Assoc. J. 2016, 10, 236-238. [CrossRef] [PubMed]

53. Aeppli, S.; Schmaus, M.; Eisen, T.; Escudier, B.; Grünwald, V.; Larkin, J.; McDermott, D.; Oldenburg, J.; Porta, C.; Rini, B. First-line treatment of metastatic clear cell renal cell carcinoma: A decision-making analysis among experts. ESMO Open 2021, 6, 100030. [CrossRef]

54. Rini, B.I.; Plimack, E.R.; Stus, V.; Gafanov, R.; Hawkins, R.; Nosov, D.; Pouliot, F.; Alekseev, B.; Soulieres, D.; Melichar, B.; et al Pembrolizumab plus axitinib versus sunitinib for advanced renal-cell carcinoma. N. Engl. J. Med. 2019, 380, 1116-1127. [CrossRef]

55. Sharma, R.; Kadife, E.; Myers, M.; Kannourakis, G.; Prithviraj, P.; Ahmed, N. Determinants of resistance to VEGF-TKI and immune checkpoint inhibitors in metastatic renal cell carcinoma. J. Exp. Clin. Cancer Res. 2021, 40, 186. [CrossRef]

56. Deleuze, A.; Saout, J.; Dugay, F.; Peyronnet, B.; Mathieu, R.; Verhoest, G.; Bensalah, K.; Crouzet, L.; Laguerre, B.; Belaud-Rotureau, M.A.; et al. Immunotherapy in renal cell carcinoma: The Future Is Now. Int. J. Mol. Sci. 2020, 21, 2532. [CrossRef]

57. Buti, S.; Bersanelli, M.; Sikokis, A.; Maines, F.; Facchinetti, F.; Bria, E.; Ardizzoni, A.; Tortora, G.; Massari, F. Chemotherapy in metastatic renal cell carcinoma today? A systematic review. Anticancer Drugs 2013, 24, 535-554. [CrossRef] [PubMed]

58. Pang, H.; Jia, W.; Hu, Z. Emerging applications of metabolomics in clinical pharmacology. Clin. Pharmacol. Ther. 2019, 106, 544-556. [CrossRef]

59. Clayton, T.A.; Lindon, J.C.; Cloarec, O.; Antti, H.; Charuel, C.; Hanton, G.; Provost, J.P.; Le Net, J.L.; Baker, D.; Walley, R.J.; et al. Pharmaco-metabonomic phenotyping and personalized drug treatment. Nature 2006, 440, 1073-1077. [CrossRef]

60. Elbadawi-Sidhu, M.; Fiehn, O. Pharmacometabolomics as the key to personalised medicine. Drug Rev. 2016, 3, $22-25$.

61. Katsila, T.; Konstantinou, E.; Lavda, I.; Malakis, H.; Papantoni, I.; Skondra, L.; Patrinos, G.P. Pharmacometabolomics-aided pharmacogenomics in autoimmune disease. EBioMedicine 2016, 5, 40-45. [CrossRef]

62. Rattner, J.; Bathe, O.F. Monitoring for response to antineoplastic drugs: The potential of a metabolomic approach. Metabolites 2017, 7, 60. [CrossRef]

63. Zhang, A.; Sun, H.; Wang, X. Serum metabolomics as a novel diagnostic approach for disease: A systematic review. Anal. Bioanal. Chem. 2012, 404, 1239-1245. [CrossRef] [PubMed]

64. Vorkas, P.A.; Abellona, U.M.; Li, J.V. Tissue multiplatform-based metabolomics/metabonomics for enhanced metabolome coverage. Methods Mol. Biol. 2018, 1738, 239-260. [CrossRef] [PubMed] 
65. Joshi, A.; Roberts, M.J.; Alinezhad, S.; Williams, E.D.; Vela, I. Challenges, applications and future directions of precision medicine in prostate cancer-The role of organoids and patient-derived xenografts. BJU Int. 2020, 126, 65-72. [CrossRef]

66. Kapalczynska, M.; Kolenda, T.; Przybyla, W.; Zajaczkowska, M.; Teresiak, A.; Filas, V.; Ibbs, M.; Blizniak, R.; Luczewski, L.; Lamperska, K. 2D and 3D cell cultures-A comparison of different types of cancer cell cultures. Arch. Med. Sci. 2018, 14, 910-919. [CrossRef]

67. Yoshida, G.J. Applications of patient-derived tumor xenograft models and tumor organoids. J. Hematol. Oncol. 2020, 13, 4. [CrossRef]

68. Ren, J.-L.; Zhang, A.-H.; Kong, L.; Wang, X.-J. Advances in mass spectrometry-based metabolomics for investigation of metabolites. RSC Adv. 2018, 8, 22335-22350. [CrossRef]

69. Monteiro, M.S.; Carvalho, M.; Bastos, M.L.; Guedes de Pinho, P. Metabolomics analysis for biomarker discovery: Advances and challenges. Curr. Med. Chem. 2013, 20, 257-271. [CrossRef]

70. Bhinderwala, F.; Wase, N.; DiRusso, C.; Powers, R. Combining mass spectrometry and NMR improves metabolite detection and annotation. J. Proteome Res. 2018, 17, 4017-4022. [CrossRef] [PubMed]

71. Lima, A.R.; Pinto, J.; Amaro, F.; Bastos, M.L.; Carvalho, M.; Guedes de Pinho, P. Advances and perspectives in prostate cancer biomarker discovery in the last 5 years through tissue and urine metabolomics. Metabolites 2021, 11, 181. [CrossRef]

72. Mastrangelo, A.; Ferrarini, A.; Rey-Stolle, F.; Garcia, A.; Barbas, C. From sample treatment to biomarker discovery: A tutorial for untargeted metabolomics based on GC-(EI)-Q-MS. Anal. Chim. Acta 2015, 900, 21-35. [CrossRef] [PubMed]

73. Yi, L.; Dong, N.; Yun, Y.; Deng, B.; Ren, D.; Liu, S.; Liang, Y. Chemometric methods in data processing of mass spectrometry-based metabolomics: A review. Anal. Chim. Acta 2016, 914, 17-34. [CrossRef] [PubMed]

74. Karaman, I. Preprocessing and pretreatment of metabolomics data for statistical analysis. Adv. Exp. Med. Biol. 2017, 965, 145-161. [CrossRef]

75. Azad, R.K.; Shulaev, V. Metabolomics technology and bioinformatics for precision medicine. Brief. Bioinform. 2019, 20 , 1957-1971. [CrossRef]

76. Xia, J.; Wishart, D.S. Using MetaboAnalyst 3.0 for comprehensive metabolomics data analysis. Curr. Protoc. Bioinform. 2016, 55, 14.10.11-14.10.91. [CrossRef]

77. Kanehisa, M.; Goto, S. KEGG: Kyoto encyclopedia of genes and genomes. Nucleic Acids Res. 2000, 28, 27-30. [CrossRef]

78. Lodi, A.; Ronen, S.M. Magnetic resonance spectroscopy detectable metabolomic fingerprint of response to antineoplastic treatment. PLOS ONE 2011, 6, 26155. [CrossRef]

79. Qu, F.; Gu, Y.; Wang, Q.; He, M.; Zhou, F.; Sun, J.; Wang, G.; Peng, Y. Metabolomic profiling to evaluate the efficacy of proxalutamide, a novel androgen receptor antagonist, in prostate cancer cells. Invest. New Drugs 2020, 38, 1292-1302. [CrossRef]

80. Sun, J.; Bok, R.A.; DeLos Santos, J.; Upadhyay, D.; DeLos Santos, R.; Agarwal, S.; Van Criekinge, M.; Vigneron, D.B.; Aggarwal, R.; Peehl, D.M.; et al. Resistance to androgen deprivation leads to altered metabolism in human and murine prostate cancer cell and tumor models. Metabolites 2021, 11, 139. [CrossRef] [PubMed]

81. Kailavasan, M.; Rehman, I.; Reynolds, S.; Bucur, A.; Tozer, G.; Paley, M. NMR-based evaluation of the metabolic profile and response to dichloroacetate of human prostate cancer cells. NMR Biomed. 2014, 27, 610-616. [CrossRef] [PubMed]

82. Ananieva, E.A.; Wilkinson, A.C. Branched-chain amino acid metabolism in cancer. Curr. Opin. Clin. Nutr. Metab. Care 2018, 21, 64-70. [CrossRef]

83. Hatakeyama, H.; Fujiwara, T.; Sato, H.; Terui, A.; Hisaka, A. Investigation of metabolomic changes in sunitinib-resistant human renal carcinoma 786-O cells by capillary electrophoresis-time of flight mass spectrometry. Biol. Pharm. Bull. 2018, 41, 619-627. [CrossRef] [PubMed]

84. Saylor, P.J.; Karoly, E.D.; Smith, M.R. Prospective study of changes in the metabolomic profiles of men during their first three months of androgen deprivation therapy for prostate cancer. Clin. Cancer Res. 2012, 18, 3677-3685. [CrossRef]

85. Huang, G.; Liu, X.; Jiao, L.; Xu, C.; Zhang, Z.; Wang, L.; Li, Y.; Yang, C.; Zhang, W.; Sun, Y. Metabolomic evaluation of the response to endocrine therapy in patients with prostate cancer. Eur. J. Pharmacol. 2014, 729, 132-137. [CrossRef] [PubMed]

86. Madhu, B.; Shaw, G.L.; Warren, A.Y.; Neal, D.E.; Griffiths, J.R. Response of Degarelix treatment in human prostate cancer monitored by HR-MAS (1)H NMR spectroscopy. Metabolomics 2016, 12, 120. [CrossRef]

87. Chi, J.T.; Lin, P.H.; Tolstikov, V.; Oyekunle, T.; Chen, E.Y.; Bussberg, V.; Greenwood, B.; Sarangarajan, R.; Narain, N.R.; Kiebish, M.A.; et al. Metabolomic effects of androgen deprivation therapy treatment for prostate cancer. Cancer Med. 2020, 9, 3691-3702. [CrossRef]

88. Zheng, H.; Zhu, Y.; Shao, X.; Cai, A.; Dong, B.; Xue, W.; Gao, H. Distinct metabolic signatures of hormone-sensitive and castration-resistant prostate cancer revealed by a (1)H NMR-based metabolomics of biopsy tissue. J. Proteome Res. 2020, 19, 3741-3749. [CrossRef]

89. Lin, H.M.; Mahon, K.L.; Weir, J.M.; Mundra, P.A.; Spielman, C.; Briscoe, K.; Gurney, H.; Mallesara, G.; Marx, G.; Stockler, M.R. A distinct plasma lipid signature associated with poor prognosis in castration-resistant prostate cancer. Int. J. Cancer 2017, 141, 2112-2120. [CrossRef]

90. Qu, F.; Gu, Y.; Xue, M.; He, M.; Zhou, F.; Wang, G.; Peng, Y. Impact of therapy on cancer metabolism in high-risk localized prostate cancer treated with neoadjuvant docetaxel and androgen deprivation therapy. Prostate 2021, 81, 560-571. [CrossRef] [PubMed]

91. Butler, L.M.; Centenera, M.M.; Swinnen, J.V. Androgen control of lipid metabolism in prostate cancer: Novel insights and future applications. Endocr. Relat. Cancer 2016, 23, 219-227. [CrossRef] 
92. Wen, H.; Lee, S.; Zhu, W.G.; Lee, O.J.; Yun, S.J.; Kim, J.; Park, S. Glucose-derived acetate and ACSS2 as key players in cisplatin resistance in bladder cancer. Biochim. Biophys. Acta Mol. Cell Biol. Lipids 2019, 1864, 413-421. [CrossRef]

93. Yang, C.; Sun, X.; Wang, H.; Lu, T.; Wu, K.; Guan, Y.; Tang, J.; Liang, J.; Sun, R.; Guo, Z.; et al. Metabolomic profiling identifies novel biomarkers and mechanisms in human bladder cancer treated with submucosal injection of gemcitabine. Int. J. Mol. Med. 2019, 44, 1952-1962. [CrossRef]

94. Sato, T.; Kawasaki, Y.; Maekawa, M.; Takasaki, S.; Morozumi, K.; Sato, M.; Shimada, S.; Kawamorita, N.; Yamashita, S.; Mitsuzuka, K.; et al. Metabolomic analysis to elucidate mechanisms of sunitinib resistance in renal cell carcinoma. Metabolites 2020, 11, 1. [CrossRef] [PubMed]

95. Mock, A.; Zschabitz, S.; Kirsten, R.; Scheffler, M.; Wolf, B.; Herold-Mende, C.; Kramer, R.; Busch, E.; Jenzer, M.; Jager, D.; et al. Serum very long-chain fatty acid-containing lipids predict response to immune checkpoint inhibitors in urological cancers. Cancer Immunol. Immunother. 2019, 68, 2005-2014. [CrossRef]

96. Jobard, E.; Blanc, E.; Negrier, S.; Escudier, B.; Gravis, G.; Chevreau, C.; Elena-Herrmann, B.; Tredan, O. A serum metabolomic fingerprint of bevacizumab and temsirolimus combination as first-line treatment of metastatic renal cell carcinoma. Br. J. Cancer 2015, 113, 1148-1157. [CrossRef] [PubMed]

97. Li, H.; Bullock, K.; Gurjao, C.; Braun, D.; Shukla, S.A.; Bossé, D.; Lalani, A.-K.A.; Gopal, S.; Jin, C.; Horak, C. Metabolomic adaptations and correlates of survival to immune checkpoint blockade. Nat. Commun. 2019, 10, 4346. [CrossRef]

98. Miranda-Goncalves, V.; Lameirinhas, A.; Henrique, R.; Baltazar, F.; Jeronimo, C. The metabolic landscape of urological cancers: New therapeutic perspectives. Cancer Lett. 2020, 477, 76-87. [CrossRef]

99. Bellmunt, J.; Szczylik, C.; Feingold, J.; Strahs, A.; Berkenblit, A. Temsirolimus safety profile and management of toxic effects in patients with advanced renal cell carcinoma and poor prognostic features. Ann. Oncol. 2008, 19, 1387-1392. [CrossRef] [PubMed]

100. Wettersten, H.I.; Aboud, O.A.; Lara, P.N., Jr.; Weiss, R.H. Metabolic reprogramming in clear cell renal cell carcinoma. Nat. Rev. Nephrol. 2017, 13, 410-419. [CrossRef] [PubMed] 